\title{
Process based inventory of isoprenoid emissions from European forests: model comparisons, current knowledge and uncertainties
}

\author{
T. Keenan ${ }^{1}$, Ü. Niinemets ${ }^{2}$, S. Sabate ${ }^{1,3}$, C. Gracia ${ }^{1,3}$, and J. Peñuelas ${ }^{1,4}$ \\ ${ }^{1}$ CREAF, Autonomous University of Barcelona (UAB), 08193 Barcelona, Spain \\ ${ }^{2}$ Institute of Agricultural and Environmental Sciences, Estonian University of Life Sciences, Kreutzwaldi 1, \\ Tartu 51014, Estonia \\ ${ }^{3}$ Department of Ecology, University of Barcelona (UB), 08007 Barcelona, Spain \\ ${ }^{4}$ Global Ecology Unit CSIC-CEAB-CREAF, CREAF, Edifici C, Universitat Autònoma de Barcelona, 08193 Bellaterra, Spain
}

Received: 7 January 2009 - Published in Atmos. Chem. Phys. Discuss.: 6 March 2009

Revised: 9 June 2009 - Accepted: 10 June 2009 - Published: 19 June 2009

\begin{abstract}
Large uncertainties exist in our knowledge of regional emissions of non-methane biogenic volatile organic compounds (BVOC). We address these uncertainties through a two-pronged approach by compiling a state of the art database of the emissions potentials for 80 European forest species, and by a model assessment and inter-comparison, both at the local and regional scale, under present and projected future climatic conditions. We coupled three contrasting isoprenoid models with the ecophysiological forest model GOTILWA+ to evaluate leaf and ecosystem isoprenoid emissions, build an emissions inventory for European forests, and to consider model behaviour in present climate and under projected future climate change conditions. Hourly, daily and annual isoprene emissions as simulated by the models were evaluated against flux measurements. The validation highlighted a general model capacity to capture gross fluxes but inefficiencies in capturing short term variability. A regional inventory of isoprenoid emissions for European forests was created using each of the three modelling approaches. The models agreed on an average European emissions budget of $1.03 \mathrm{TgCa}^{-1}$ for isoprene and $0.97 \mathrm{TgCa}^{-1}$ for monoterpenes for the period $1960-1990$, which was dominated by a few species with largest aerial coverage. Species contribution to total emissions depended both on species emission potential and geographical distribution. For projected future climate conditions, however, emissions budgets proved highly model dependent, illustrating the current uncertainty associated with isoprenoid emissions responses to potential future conditions.
\end{abstract}

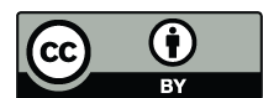

Correspondence to: $\mathrm{T}$. Keenan (t.keenan@creaf.uab.es)
These results suggest that current model estimates of isoprenoid emissions concur well, but future estimates are highly uncertain. We conclude that development of reliable models is highly urgent, but for the time being, future BVOC emission scenario estimates should consider results from an ensemble of available emission models.

\section{Introduction}

Non-methane biogenic volatile organic compounds (BVOC), emitted by most plant species, is a heterogeneous compound class made up of a wide range of reactive volatile hydrocarbons. European forest species emit large amounts of BVOCs, in particular, volatile isoprenoids: isoprene $\left(\mathrm{C}_{5} \mathrm{H}_{8}\right)$ and monoterpenes $\left(\mathrm{C}_{10} \mathrm{H}_{16}\right)$ (Arneth et al., 2007; Guenther et al., 1995; Simpson et al., 1999).

For many BVOCs, the function for the emitting plants is not entirely clear (Owen and Peñuelas, 2005; Peñuelas and Llusia, 2004; Sharkey and Singsaas, 1995), although the emissions seem to play multiple roles in plant protection, in particular during episodes of high photosynthetic photon flux density (Sharkey and Singsaas, 1995), high temperatures (Copolovici et al., 2005; Peñuelas et al., 2005; Sharkey, 2005; Sharkey and Yeh, 2001), oxidative stress (Affek and Yakir, 2002; Loreto et al., 2001; Loreto and Velikova, 2001; Velikova and Loreto, 2005), and biotic stress (Miller et al., 2005; van Poecke and Dicke, 2004).

BVOCs play a significant role in atmospheric chemistry (e.g., Fuentes et al., 2000; Gelencser et al., 2007; Helmig et al., 2006; Kanakidou et al., 2005; Szidat et al., 2006), in particular in the formation of secondary organic aerosols (Kanakidou et al., 2005) and tropospheric ozone at high light

Published by Copernicus Publications on behalf of the European Geosciences Union. 
intensities and temperatures, and in the presence of $\mathrm{NO}_{\mathrm{x}}$ (Fehsenfeld et al., 1992). Emissions from terrestrial ecosystems also cause a decrease in atmospheric hydroxyl radical $(\mathrm{OH})$ concentrations and thereby result in an increase of the lifetime of methane in the troposphere $\left(\mathrm{CH}_{4}\right)$ (Poisson et al., 2000; Roelofs and Lelieveld, 2000). The emissions of BVOC have therefore far-reaching implications for air quality (e.g., Bell and Ellis, 2004), both globally and locally. The effects of biogenic emissions on methane lifetime and aerosols can further lead to important feedbacks between emissions and climate change (Kulmala et al., 2004; Peñuelas and Llusià, 2003).

Due to their importance in air chemistry and climatic processes, regional-scale emission inventories are needed to predict regional air quality as well as simulate future climatic conditions (e.g., Collins et al., 2004; Kulmala et al., 2004; Tunved et al., 2006). This requires application of emission models accurately describing the responses of emissions to variation in environmental drivers (Grote and Niinemets, 2008). Temperature and radiation have been found to be the main driving factors for the emission of both isoprene and monoterpenes in broad-leaved species (Dindorf et al., 2006; Hansen and Sharkey, 2001; Monson and Fall, 1989; Loreto and Sharkey, 1990), while only temperature has been suggested to control monoterpene emissions in some conifers (Tingey et al., 1980, but see Staudt et al., 1997). These key findings have driven the development of isoprene and monoterpene emission models from simple empirical models to more process based designs.

Early emission modelling methods took an empirical approach, linking emissions directly with climatic variables (Guenther et al., 1995). These have shown to have high predictive power in some, but not in all situations (e.g., Arneth et al., 2007; Bai et al., 2006; Geron et al., 2002; Harley et al, 2004; Otter et al., 2002, 2003; Wang et al., 2007). With an improved understanding of the biochemical reaction pathways for the formation of various plant volatiles, more mechanistic models have evolved (Bäck et al., 2005; Martin et al., 2000; Niinemets et al., 1999; Niinemets and Reichstein, 2003; Zimmer et al., 2000). In these process based models, responses of key enzymatic activities to environmental variables set the internal biochemical conditions, which finally determines the emission rates. These advanced models, however, still do not describe several key physiological observations (Monson et al., 2007), such as responses to elevated $\mathrm{CO}_{2}$. So far, few attempts have been made to compare the capacity of different emission models to simulate the environmental variability in emissions encountered in the field (Arneth et al., 2007).

Emission models are almost exclusively developed at the leaf level and are then scaled, through spatial and temporal scales, to the canopy, to the stand, and finally to the region level. This requires the coupling of an emission model with a process-based SVAT (soil-vegetation-atmosphere transfer) model. Such models describe leaf scale processes, set the micrometeorological canopy conditions which drive these processes, and describe the biomass and foliage distribution throughout the canopy (Baldocchi et al., 1999; Grote, 2006; Lamb et al., 1993; Lenz et al., 1997; Schaab et al., 2003). Such an approach also requires reliable information of emission potentials of each individual species.

The BVOC emission potential $\left(E_{S}\right.$, the maximum emission rate under standard conditions) of terrestrial vegetation is one of the most important variables in modelling BVOC emissions (Arneth et al., 2008b; Grote and Niinemets, 2008). $E_{S}$ strongly varies among species with values near zero to greater than $100 \mu \mathrm{g} \mathrm{g}_{\text {leaf }}^{-1} \mathrm{~h}^{-1}$ (Kesselmeier and Staudt, 1999; Wiedinmyer et al., 2004). This high variability also exists between similar taxonomic entities (e.g., Owen et al., 2001) such that the emission potential of species of the same genera may be vastly different (Benjamin et al., 1996; Kesselmeier and Staudt, 1999). For instance, among Quercus species, some species are known to be strong isoprene emitters, some monoterpene emitters, and some species have emissions close to zero (Kesselmeier and Staudt, 1999). While extensive emission potential databases have been collated over recent years (Kesselmeier and Staudt, 1999; Wiedinmyer et al., 2004, http://bai.acd.ucar.edu/Data/BVOC/index. shtml; Nick Hewitt's database: http://www.es.lancs.ac.uk/ cnhgroup/iso-emissions.pdf), these databases include all the estimates made so far without a critical revision. Even for a single species, a large variability exists in the emission factor estimates that is currently not understood. There is a general tendency of modelling studies to use average values of emission factors proposed by emission factor databases (Guenther et al., 2006; Parra et al., 2004; Simpson et al., 1995). However, as non-standardized methods have been used in the estimation of emission factors in the past, using averages of all estimates results in propagation of errors from study to study. Thus, a critical revision of the emission factors is pertinent to standardize the emission factor estimates as much as possible.

In this paper, we first embedded three different isoprenoid emission models into a process based terrestrial biogeochemical model, thus providing a bottom up approach both to quantify the isoprene and monoterpenes emissions being released into the atmosphere under present day and potential future climate change. With these new tools we tested the possible variability due to differences in leaf level models. For this, isoprene emission flux measurements were used to compare diurnal and seasonal emission predictions at two forest sites with contrasting forest structure and species composition, one in the south of France and the other in Michigan, USA. We further revised the emission potentials for 80 dominant European forest species both occurring naturally and in forest plantations. In all cases, original studies were examined and a new consensus estimate was derived for each species. Using these basal emission potentials we derive an emission inventory for both isoprene and monoterpenes emissions from European forests under 
current climatic conditions using the three different modelling approaches. Finally, European forests were used as an example to analyse and compare large scale model performances under future climatic conditions.

\section{Materials and methods}

\subsection{Leaf level emission algorithms}

A recent model comparison study highlighted three isoprenoid emission models as possible candidates for regional or global applications (Arneth et al., 2007). The models take contrasting approaches to modelling emissions, each with different assumptions about the way environmental factors limit the emissions and with different levels of mechanistic detail. Where pertinent, modifications were made in order to ensure consistency between the models (as in Arneth et al., 2007). No direct $\mathrm{CO}_{2}$ effect on the emissions was applied in the models. The effect of $\mathrm{CO}_{2}$ on emissions has been previously reported (Rosenstiel et al., 2003), but as yet the mechanistic understanding is poor.

\subsubsection{The Guenther et al. model}

By far the most widely used models for simulation of natural isoprenoid emissions were developed by Guenther et al. (1991), and Guenther et al. (1993). Their approach was to describe the emission rates by using long-term basal emission factor for isoprene $\left(E_{I}\right)$ and monoterpenes $\left(E_{M}\right)$, and adjusting these basal emission potentials by two empirical factors, one describing the response to light intensity and the other to leaf temperature. The correlation between short term fluctuations, light intensity and leaf temperature is widely studied and much work has gone into validating the Guenther et al. model under different environmental conditions (Monson et al., 1994; Petron et al., 2001).

The emission factors used in the model are emission rates normalized to a leaf temperature $(T)$ of $30^{\circ} \mathrm{C}$ and quantum flux density $(Q)$ of $1000 \mu \mathrm{mol} \mathrm{m}{ }^{-2} \mathrm{~s}^{-1}$ (sometimes for monoterpenes normalized only to temperature) (Guenther, 1991; Guenther et al., 1993, 1995, 1997). For light and temperature dependent isoprenoid emission, the algorithms (based on the equation: $E=E_{S} C_{L} C_{T}$, where $E_{S}$ is the basal emission potential, $C_{L}$ and $C_{T}$ are the functions of quantum flux density and leaf temperature, respectively.) as outlined in Guenther et al. (2006) were used.

Parameters were determined following the original paramerisations of the Guenther et al. model, including recent algorithms developed by Guenther et al. (2006), which links parameter values to short term $(24 \mathrm{~h})$ and long term (10 days) fluctuations in temperatures and light intensity.

For some species, in particular conifers with extensive monoterpene pools with slow turnover compared with the rate of monoterpene synthesis, monoterpene emissions have been related directly to leaf temperature. In such cases, monoterpene emissions were calculated following the Guenther et al. (1993) temperature based monoterpene model, which fluctates emissions based on an empirical temperature response.

\subsubsection{The Niinemets et al. model}

The Niinemets et al. model for isoprene and monoterpene emissions takes a process-based approach, linking the emission rates to the activity of the synthase enzyme $S_{S}$ to predict the capacity of isoprenoid synthesis pathway and to foliar photosynthetic metabolism via the photosynthetic electron transport rate, $J$, to predict substrate availability for isoprenoid synthesis (Niinemets et al., 1999, 2002b). Here, the supply of dimethylallyl pyrophosphate (DMAPP) and NADPH, as affected by the rate of photosynthetic electron transport and the competitive strength of the synthase enzyme for electrons, are considered as the main controlling factors for the rate of isoprenoid synthesis.

Emission rates are calculated through the fraction of total electron flow used for the isoprenoid synthesis, the rate of photosynthetic electron transport, and the cost of isoprenoid synthesis in terms of electrons. Thus, the emissions are linked to the photosynthetic activity of the leaf with the use of only one single leaf dependent parameter, the fractional allocation of electron transport to synthase activity.

\subsubsection{The Martin et al. model}

Martin et al. (2000) developed a process based approach for isoprene emissions using the knowledge of the biochemical pathway of isoprene synthesis, thus providing a highly mechanistic model.

As the rate of isoprene emission will be governed by the rate of the slowest reaction in its biochemical pathway, the emissions can be calculated depending on which partial process is limiting under given environmental conditions. This model formulates the extent different processes in the biochemical pathway of isoprene synthase limit isoprene emission and represents the rate of emission as the minimum of three potentially rate limiting processes:

- The supply of carbon to isoprene synthase via pyruvate;

- The supply of ATP from phosphorylation;

- The temperature dependency of the isoprene synthase reaction rate.

The model applied here is a slight modification (following Arneth et al., 2007) of the original version used by Martin et al. (2000) in order to assure compatibility with the analogous expression in the model of Niinemets et al. The rate of isoprene synthesis is thus proposed to be highly dependent on the rate of supply of carbon in the form of phosphoglyceric acid (PGA) or pyruvate (from photosynthesis or photorespiration), the rate of phosphorylation to supply the ATP 
needed for the conversion of PGA/pyruvate to DMAPP and the amount and in vivo activity of the isoprene synthase enzyme (Lehning et al., 1999; Loreto and Sharkey, 1993; Monson et al., 1992), following the suggestion that Pyruvate is formed from Rubisco carboxylation about $1 \%$ of the time (Andrews and Kane, 1991).

Implicit in both the Niinemets et al. and the Martin et al. model approaches for the simulation of isoprene emission on the basis of isoprene synthase kinetics (Fall and Wildermuth, 1998) is that DMAPP concentrations must change in response to changes in light availability at any given temperature, i.e. isoprenoid emission rates are substrate-controlled. DMAPP levels have been found to vary within and between days, and varied more in plants which emitted isoprene (Rosenstiel et al., 2002).

\subsubsection{Modifying the leaf-level models to simulate long- term emission responses to environment}

All three leaf-level models provide qualitatively similar responses of isoprenoid emissions to changes in temperature and light over short term (Arneth et al., 2007). However, emission rates also adjust to long term modifications in environmental drivers, implying that it is important to consider such effects as well to simulate long-term emission dynamics.

Phenology. Phenology is known to affect isoprenoid emissions and many studies have characterized how emissions respond to phenological events (e.g., Fuentes and Wang, 1999; Kuhn et al., 2004; Monson et al., 1994; Petron et al., 2001; Wilberley et al., 2005). This effect was incorporated into each of the emission models in the same simple manner, by reducing the basal emissions potential which is used in each model by a temperature dependent scalar, $K$, ranging from 0 to 1. This scalar is calculated following Leinonen (1996), an updated version of the Pelkonen and Hari (1980) approach for calculating the seasonal variations in photosynthetic potential. So, in this way, emissions are scaled in parallel with the photosynthetic potential. In the case of deciduous phenology (Smith et al., 2001) this also leads to a decreasing isoprenoid emission capacity in senescing leaves before the leaves die (Arneth et al., 2007; Geron et al., 2000; Goldstein et al., 1998; Pressley et al., 2005).

Soil water availability effects. Isoprenoid emissions are effected by seasonal water stress, though the exact extent and mechanisms behind the emission responses to water stress are yet unclear (Grote and Niinemets, 2008). A strong reduction of emissions is observed in most cases after strong seasonal water stress (Lavoir et al., 2009; Llusia and Peñuelas, 1998; Pegoraro et al., 2004), though in some cases an increase in emissions has been reported (Pegorara et al., 2007). In the model GOTILWA+, to which the emissions models are coupled, photosynthesis is reduced directly during water stress through a reduction in the rate of electron trans- port, and the maximum carboxylation capacity (Keenan et al., 2009). All three emissions models are indirectly influenced by the soil moisture dependence of stomatal conductance which influences the leaf temperature estimated by GOTILWA+. The Guenther et al. model also includes a direct effect of soil water stress. Emissions are reduced during water stress directly in parallel with photosynthesis, by applying the same function which reduces photosynthetic potential (Grote et al., 2009; Guenther et al., 2006; Keenan et al., 2009). Stress affects the Niinemets et al. model emissions indirectly, as the drought-dependent reductions in the rate of electron transport, $J_{T}$, lead to reduced substrate availability and thereby to reduced emissions. The Martin et al. model was modified in a similar manner as the Guenther et al. model, but here the water stress function was also applied to the supply of emission precursors.

\subsubsection{Species-specific emission potentials}

Calculated total emissions are highly dependent on the assigned emission potentials $E_{I}$ and $E_{M}$ that are directly applied in the Guenther et al. model, and determine the isoprenoid synthase activities in the Niinemets et al. and Martin et al. models. The emission potentials have recently been concluded to be one of the most important parameters for modelling regional emissions (Arneth et al., 2008b; Grote and Niinemets, 2008). In most large-scale modelling studies, the values initially specified by Guenther et al. (1995) are applied. Since then, much more information has become available and been integrated into previous estimates (Guenther et al., 2006). However, for most ecosystems and vegetation types measurements of BVOC emissions are still scarce or absent (Grote and Niinemets, 2008; Guenther et al., 2006). Due to the large variation within families, assigning general emission rates to plant functional types is often done by subjective judgment. It often occurs that very different emission potentials are assigned to a certain functional type or species in different modelling studies, leading to very different results (Arneth et al., 2008b for review). We address this problem through a thorough critical literature review to compile the state of the art knowledge of species-specific emission potentials for 80 species included in the GOTILWA+ forest model (Table 1).

In this analysis, all previous known reports were reassessed with regards to measurement methods and derivation of standardized emission potentials. As there is considerable uncertainty in actual light and temperature environment in whole-tree and whole-branch enclosure studies that can seriously affect standardization of emission rates, we preferred estimates conducted with single leaf enclosures. As a variety of temperature responses have been used to convert the emission rates to standardized conditions of $30^{\circ} \mathrm{C}$ and $1000 \mu \mathrm{mol} \mathrm{m} \mathrm{s} \mathrm{s}^{-1}$, whenever actual response curves were absent, we reconverted the data using the 
Table 1. Compilation of isoprene $\left(E_{I}\right)$ and monoterpene $\left(E_{M}\right)$ emission factors and projected leaf dry mass per unit area $\left(M_{A}\right)$ in 80 dominant species of European forests.

\begin{tabular}{|c|c|c|c|c|c|c|}
\hline \multirow[t]{2}{*}{ Species $^{\mathrm{a}}$} & \multirow[t]{2}{*}{$M_{A}\left(\mathrm{~g} \mathrm{~m}^{-2}\right)^{\mathrm{b}}$} & \multicolumn{2}{|r|}{ Isoprene } & \multicolumn{3}{|c|}{ Monoterpenes } \\
\hline & & $E_{I}\left(\mu \mathrm{g} \mathrm{g}^{-1} \mathrm{~h}^{-1}\right)$ & Reference & $E_{M}\left(\mu \mathrm{g} \mathrm{g}^{-1} \mathrm{~h}^{-1}\right)$ & Light dependency ${ }^{\mathrm{c}}$ & Reference \\
\hline Abies alba & 185 & 0 & {$[40],[85]$} & 3 & $\mathrm{~N}$ & [3] \\
\hline Abies borisii-regis & 185 & 18.4 & [35] & 2.7 & $\mathrm{~N}$ & [35] \\
\hline Abies cephalonica & 185 & 0 & d & 3 & $\mathrm{~N}$ & d \\
\hline Acer campestre & 95 & 0 & {$[85],[88]$} & 2 & $\mathrm{Y}$ & $\mathrm{e}$ \\
\hline Acer opalus & 57 & 0 & e & 2 & $\mathrm{Y}$ & $\mathrm{e}$ \\
\hline Acer platanoides & 57 & 0 & {$[34]$} & 2 & $\mathrm{Y}$ & $\mathrm{e}$ \\
\hline Acer spp. & 70 & 0 & {$[26],[51],[85],[88],[99]$} & 2 & $\mathrm{Y}$ & [15], [51], [99] \\
\hline Alnus cordata & 80 & 0 & [73] & 1.5 & $\mathrm{Y}$ & {$[52],[88]$} \\
\hline Alnus glutinosa & 77 & 0.2 & [98] & 6.9 & $\mathrm{Y}$ & {$[66],[88],[98]$} \\
\hline Alnus incana & 72 & 0 & {$[12],[87],[88]$} & 0.6 & $\mathrm{Y}$ & {$[30]$} \\
\hline Arbutus andrachne & 220 & 0.1 & $\mathrm{f}$ & 0.1 & $\mathrm{Y}$ & $\mathrm{f}$ \\
\hline Arbutus unedo & 148 & 0.1 & {$[24],[60],[63],[66],[77]$} & 0.1 & $\mathrm{Y}$ & {$[59],[60],[62],[66]$} \\
\hline Betula pendula & 82 & 0 & {$[29],[50],[65]$} & 6.7 & $\mathrm{Y}$ & {$[28],[29]$} \\
\hline Betula pubescens & 66 & 0 & {$[18],[87]$} & 2.6 & $\mathrm{Y}$ & {$[28]$} \\
\hline Buxus sempervirens & 137 & 11 & {$[59],[61],[62],[64]$} & 0 & & {$[59],[62]$} \\
\hline Carpinus betulus & 80 & 0 & [50] & 1.5 & $\mathrm{Y}$ & {$[50],[98]$} \\
\hline Carpinus orientalis & 80 & 0 & $\mathrm{~g}$ & 1.5 & $\mathrm{Y}$ & $\mathrm{g}$ \\
\hline Castanea sativa & 75 & 0 & {$[66],[73]$} & 10.9 & $\mathrm{Y}$ & {$[66],[73]$} \\
\hline Cedrus atlantica & 200 & 0 & [73] & 0.7 & $\mathrm{~N}$ & {$[9],[96]$} \\
\hline Cedrus deodara & 200 & 0 & {$[9],[73],[96],[97]$} & 0.7 & $\mathrm{~N}$ & {$[9],[96]$} \\
\hline Cupressus sempervirens & 250 & 0.1 & {$[21],[23],[26]$} & 0.7 & $\mathrm{~N}$ & {$[21],[23],[26]$} \\
\hline Eucalyptus spp. & 130 & 38.7 & {$[15],[19],[27],[36],[42],[67],[89],[91]$} & 2.7 & $\mathrm{~N}$ & {$[15],[26],[36],[57],[67],[89],[91]$} \\
\hline Fagus sylvatica & 63 & 0 & {$[50],[70],[75],[88]$} & 8.9 & $\mathrm{Y}$ & {$[11],[56],[93],[98]$} \\
\hline
\end{tabular}

${ }^{a}$ Species nomenclature follows ARS/GRIN online database (USDA, ARS, National Genetic Resources Program. Germplasm Resources Information Network - (GRIN), National Germplasm Resources Laboratory, Beltsville, Maryland, http://www.ars- grin.gov/cgi-bin/npgs/html/index.pl); ${ }^{b}$ based on the original studies and Niinemets (1999) and Wright et al. (2004) (GLOPNET) databases; ${ }^{\mathrm{c}} \mathrm{N}-$ the emission is only controlled by temperature, $\mathrm{Y}-$ the emission is controlled by both light and temperature, $\mathrm{N} / \mathrm{Y}(\mathrm{xx})$ part of the emission is controlled by temperature only, part by both temperature and light. The number in parenthesis shows the percentage of emission controlled by both light and temperature; ${ }^{\mathrm{d}}$ based on default values for Abies that was derived from references [21], [23], [26] for isoprene and [21], [23], [26], [85] for monoterpenes; ${ }^{\mathrm{e}}$ based on default values for Acer that was derived from references [26], [51], [85], [88], [99] for isoprene and [15], [18], [25], [26], [96], [99] for monoterpenes; ${ }^{\mathrm{f}}$ based on values for Arbutus unedo; ${ }^{\mathrm{g}}$ based on values of Carpinus betulus; ${ }^{\mathrm{h}}$ based on values for Fagus sylvatica; ${ }^{\mathrm{i}}$ based on values for Fraxinus excelsior; ${ }^{\mathrm{j}}$ based on values for Juniperus oxycedrus and Juniperus phoenicea; ${ }^{\mathrm{k}}$ based on values of Larix decidua; ${ }^{1}$ based on values for Phillyrea angustifolia; ${ }^{\mathrm{m}}$ based on default values for Pinus that were derived from [9], [15], [44], [46], [59], [60], [66], [73], [77], [80], [82], [92], [96] for isoprene and [21], [23], [26], [52], [96] for monoterpenes; $\mathrm{n}$ average values for Populus alba and P. tremula; ${ }^{\circ}$ average values for Populus deltoides and Populus nigra; $\mathrm{P}$ based on values for Tilia cordata Reference index:
[1] Arrey et al., 1991a; [2] Arey et al., 1991b; [3] Benjamin et al., 1996; [4] Benjamin et al., 1998; [5] Bertin et al.,. 1997; [6] Brilli et al., 2007; [7] Broecking et al.,. 2003; [8] Ciccioli et al., 1997; [9] Corchnoy et al., 1992; [10] Csiky et al., 1999; [11] Dindorf et al., 2006; [12] Drewitt et al., 1998; [13] Dutaur et al., 1996; [14] Duyzer et al., 1993; [15] Evans et al., 1982; [16] Fares et al., 2006; [17] Flyckt et al., 1979; [18] Flyckt et al., 1980; [19] Funk et al., 2006; [20] Geron et al., 2001; [21] Geron et al., 1994; [22] Grabmer et al., 2006; [23] Guenther et al., 1997; [24] Guenther et al., 2000; [ 25] Guenther et al., 1996; [26]
Guenther et al., 1994; [27] Guenther et al., 1991; [28] Hakola et al., 2001; [29] Hakola et al., 1998; [30] Hakola et al., 1999; [31] Hakola et al., 2003; [32] Hansen et al., 1996; [33] Hansen et al., 1997; [34] Guenther et al., 1994; [27] Guenther et al., 1991; [28] Hakola et a.., 2001; [29] Hakola et al., 1998; [30] Hakola et al., 1999; [31] Hakola et al., 2003; [32] Hansen et al., 1996; [33] Hansen et al., 1997; [34] al., 2001; [43] Kempf et al., 1996; [44] Kesselmeier et al., 1997; [45] Kesselmeier et al., 1998; [46] Kesselmeier et al., 1999; [47] Klinger et al., 2002; [48] Knöppel et al., 1981; [49] Komenda et al., 2002; [50] König et al., 1995; [51] Lamb et al., 1983; [52] Lenz et al., 2001; [53] Lindskog and Potter, 1995; [54] Litvak et al., 1999; [55] Llusià and Peñuelas, 2000; [56] Luchetta, 1999; [57] Noe et al., 2008; [58] Ormeño et al., 2007; [59] Owen, 1998; [60] Owen et al., 1997; [61] Owen et al., 1998; [62] Owen et al., 2001; [63] Owen et al., 2002; [64] Owen and Hewitt, 2000; [65] Owen et al., 2003; [66] Pio et al., 1993; [67] Pio et al., 1996; [68] Pio et al., 2005; [69] Possell et al., 2004; [70] Puxbaum et al., 1997; [71] Rabong and Steinbrecher, 1995; [72] Rapparini et al., 2004; [73] Rasmussen, 1978; [74] Sabillón and Cremades, 2001; [75] Schuh et al., 1997; [76] Schürmann, 1993; [77] Seufert et al., 1997; [78] Shao et al., 2001; [79] Simon et al., 1994; [80] Staudt, 1997; [81] Staudt and Bertin, 1998; [82] Staudt et al., 1997; [83] Staudt et al., 2004; [84] Steinbrecher, 1994; [85] Steinbrecher, 1997; [86] Steinbrecher and Hauff, 1996; [87] Steinbrecher et al., 1997; [88] Steinbrecher et al., 1993; [89] Street et al., 1997a; [90] Street et al., 1996; [91] Street et al., 1997b; [92] Street et al., 1997c; [93] Tollsten and Müller, 1996; [94] Winer et al., 1989; [95] Winer et al., 1992; [96] Winer et al., 1983; [97] Xiaoshan et al., 2000; [98] Zemankova, 2007; [99] Zimmerman, 1979.

Guenther et al. (1993) original model. In all cases, units were homogenized (e.g., $\mu \mathrm{g} \mathrm{C} \mathrm{g} \mathrm{gr}^{-1}$ often used in North American studies vs. $\mu \mathrm{g} \mathrm{BVOC} \mathrm{g} \mathrm{g}^{-1} \mathrm{hr}^{-1}$ often used in European studies).

Errors due to the use of inappropriate values of leaf dry mass per unit area, $M_{A}$, in converting area based relations to mass basis (for instance converting total leaf area based estimates using projected area-based $M_{A}$ values) were corrected. Three sources of errors were identified in $M_{A}$ values. 1) the reciprocal of $M_{A}$, SLA (in units $\mathrm{cm}^{2} \mathrm{~g}^{-1}$ ), had been used, and instead of multiplication, area/based values were divided by SLA; 2) $M_{A}$ had been calculated on the basis of total area, but emission measurements were based on projected area (mainly a problem in needle-leaved species), 3) errors in units. These errors were identified on the basis of information provided in the Material and Methods about the methods of area determination and expression of the characteristics, and on the basis of tabulated values of $M_{A}$ and the area-based emission rates. In the case of studies using literature-based $M_{A}$ values, original $M_{A}$ values were looked up from the literature.

Because of the lower sensitivity of analytical techniques in the past, and significant background level of isoprene and monoterpenes in the gas-exchange enclosures either due to isoprenoids in incoming ambient air, or adsorption/desorption processes in the cuvettes, there is considerable uncertainty in detecting minute emission rates with conventional techniques. Due to these uncertainties, emission rates less than $0.1 \mu \mathrm{g} \mathrm{g}^{-1} \mathrm{hr}^{-1}$ were set to zero in the current compilation. Only the values corresponding to fully-developed leaves in non-stressed conditions were used whenever possible. For several species included in the GOTILWA+ model, reliable emission rates were not available. For these species, emission factors of taxonomically closest species were employed (Benjamin et al., 1996 for discussion).

For broad-leaved species not included in Table 1, we used the default values of $10 \mu \mathrm{g} \mathrm{g}^{-1} \mathrm{hr}^{-1}$ for isoprene and 
Table 1. Continued.

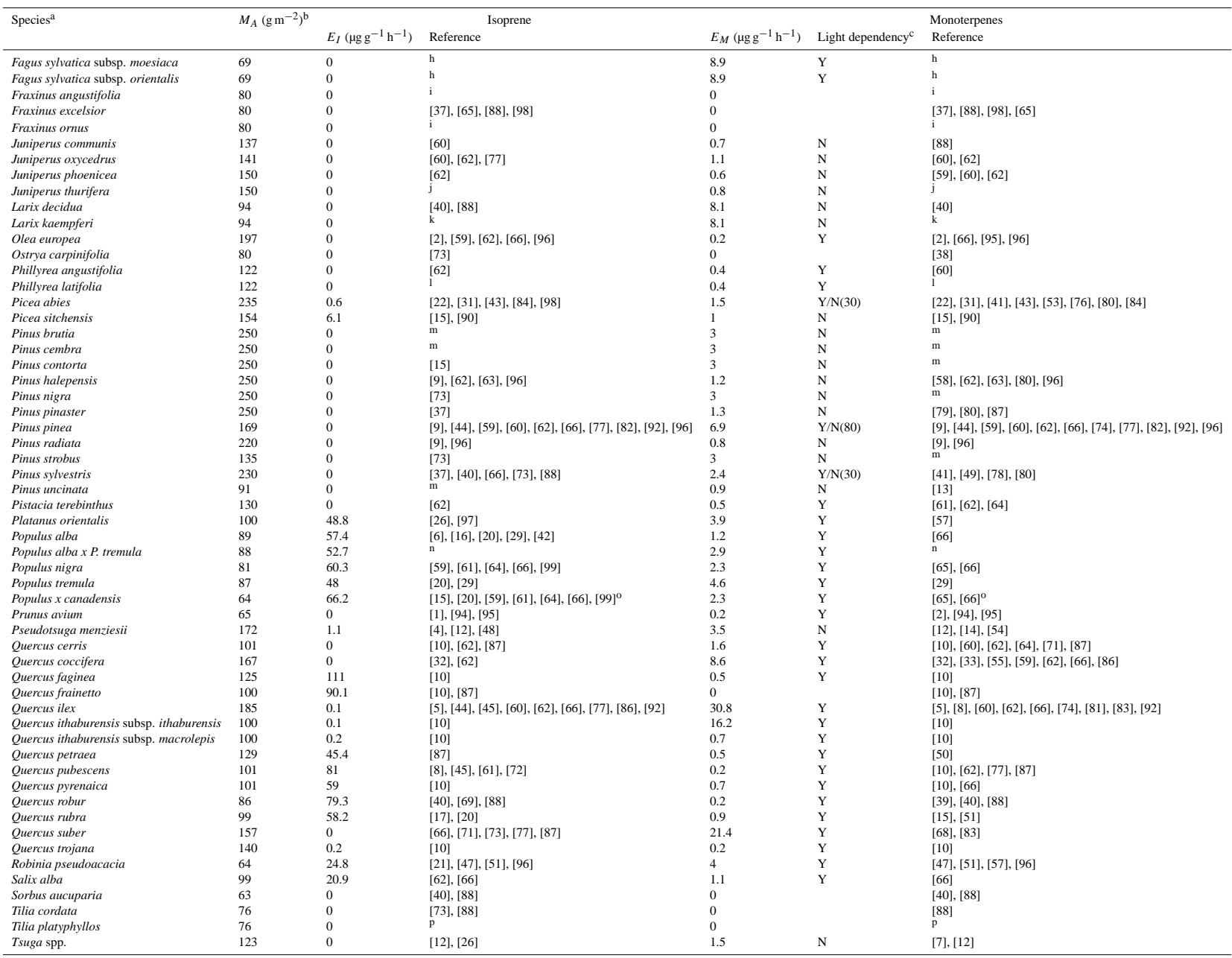

$0.2 \mu \mathrm{gg}^{-1} \mathrm{hr}^{-1}$ as suggested by Solmon et al. (2004). For conifers not included in Table 1 , the default values were $1 \mu \mathrm{gg}^{-1} \mathrm{hr}^{-1}$ for isoprene and $3 \mu \mathrm{gg}^{-1} \mathrm{hr}^{-1}$ for monoterpenes (Solmon et al., 2004).

In addition to the emission factors, for the simulation of monoterpene emissions, it is also important to know whether emissions are only temperature dependent or both light and temperature dependent. In several conifers, the emission may be both light and temperature dependent (Staudt et al., 1997; Shao et al., 2001) and information of the share or these two contrasting emission sources are provided in Table 1.

\subsection{Scaling from the leaf to the landscape}

The three emission models simulate isoprenoid emissions from any given leaf in dependence on climatic conditions. To scale from the leaf to the landscape, the emission models were coupled to the biogeochemical forest model, GOTILWA+. This model described leaf structural and chem- ical characteristics, and thus foliage physiological potentials. This model also described the microclimatic conditions and forest structure necessary to scale from the leaf to the canopy, and further to the region. Using forest inventories and regional databases of climate on a $10^{\prime} \times 10^{\prime}$ scale, simulations were run for each of the forest stands in EU15+2 (pre-enlargement Europe, Norway and Switzerland).

\subsubsection{Scaling from the leaf to the stand: the GOTILWA+ model}

Each emission model considered was coupled separately to the photosynthetic submodel of the GOTILWA+ terrestrial biogeochemical model (Gracia et al., 1999; Keenan et al., 2008; http://www.creaf.uab.es/GOTILWA+). GOTILWA+ is a process-based forest model that has been developed to simulate carbon and water fluxes from forest ecosystems and to explore how the functioning of forests is influenced by climate, tree stand structure, management techniques and soil 
properties. Carbon and water fluxes of forests are simulated for different environmental conditions, for different tree species, and under changing environmental conditions that result from either climatic modifications or from alterations in management regime.

The GOTILWA+ model includes a two-leaf canopy photosynthetic model (Wang and Leuning, 1998; Dai et al., 2004). The photosynthesis sub-model treats the $\mathrm{C}_{3}$ photosynthetic pathway. The canopy is divided into sunlit and shaded leaves, with the amount of intercepted diffuse and direct radiation depending on the time of the day, season, and the area of leaf exposed to the sun (Campbell, 1986, 1990). Foliage net assimilation rates are calculated using the Farquhar et al. (1980) photosynthesis model, with dependencies on intercepted quantum flux density, species-specific photosynthetic capacities, leaf temperature, and leaf intercellular $\mathrm{CO}_{2}$ concentration $\left(C_{i}\right)$. Stomatal conductance is calculated using the Leuning et al. model (Leuning et al., 1995) that is the advancement of the Ball et al. model (Ball et al., 1987). Water stress affects the photosynthesis-conductance coupling by directly reducing the photosynthetic potential through a nonlinear relation to soil water content (Keenan et al., 2009). Canopy isoprene and monoterpene emission rates were calculated on an hourly basis as the sum of sunlit and shaded leaf fractions using their specific leaf temperature and incident radiation values.

\subsubsection{Scaling from the stand to the region}

To supply the input data required by the model, an extensive database has been built within the framework of the European ATEAM (Advanced Terrestrial Ecosystem Analysis and Modelling) and ALARM (Assessing Large-scale Risks for biodiversity with tested Methods) projects, connecting diverse information sources at a European level and adapting them to fit the same spatial resolution of $10^{\prime} \times 10^{\prime}$. The database contains data related to forest species, forest area cover, forest structure, forest function (photosynthesis, respiration rates), soil hydrology, organic matter decomposition rates and management strategies (Schröter et al., 2005). Area explicit estimates of forest cover were made available which specify the eighty dominant forest species in Europe. Simulations were run with GOTILWA+ for each $10^{\prime} \times 10^{\prime}$ scale forested pixel in Europe $(\mathrm{EU} 15+2)$. For parameterisation of the forest structural components in GOTILWA+, three forest functional types (temperate deciduous, temperate broadleaf evergreen, and temperate needle-leaf evergreen) were considered.

\subsubsection{Scaling through time}

Simulations were run with each emission model coupled to the GOTILWA+ model for a two hundred year period from 1900 to 2100 . From 1900 to 2000, a reconstructed climatic data time series based on the CRU05 (1901-2000) monthly dataset (New et al., 1999) was used, with global atmospheric concentrations of $\mathrm{CO}_{2}$ from 1901 to 2000 obtained from the Carbon Cycle Model Linkage Project (McGuire et al., 2001). The IPCC socioeconomic analysis (IPCC, 2001, 2007) resolved several possible standard scenarios for $\mathrm{CO}_{2}$ emissions (A1, A2, B2, B1). Different global circulation models use these scenarios to generate future climatic projections. In this work we have applied the climatic projection for period 2001-2100 generated by the HadCM3 global circulation model using the A2 scenario as an indicator for the effect of possible future climate change on the BVOC emissions. This scenario uses an estimated increase in atmospheric $\mathrm{CO}_{2}$ to $709 \mathrm{ppm}$ by 2080 . Using this scenario, HadCM3 predicts an increase in temperature of $2.8^{\circ} \mathrm{C}$ by 2080 for the area included in this study (in comparison to the average temperatures for the 1960-1990 period), and regional changes in precipitation. Species distributions for the past 100 years is assumed equivalent to current species distribution, and no explicit changes were applied for simulations over the $21 \mathrm{st}$ century.

\subsection{Stand scale validation}

Recent developments in direct methodologies such as eddycovariance, disjunct eddy covariance, relaxed eddy accumulation and disjunct eddy accumulation techniques provide high quality quantitative measurements of isoprenoid emissions (Businger and Oncley, 1990, Hills and Guenther, 1998; Rinne et al., 2000; Karl et al., 2002; Ciccioli et al., 2003, Spirig et al., 2005). So far, few such measurements are available over forest ecosystems. Here, one relatively short-term series (26-days) of diurnal time-courses of isoprene emissions with a half-hour time-resolution (Arneth et al., 2007) and one long-term series of seasonal time-courses of isoprene fluxes with daily resolution (Pressley et al., 2005, 2006) are used to validate the implementation of the isoprene models at the canopy level. Three simulations were run at each site, one for each model coupled to the GOTILWA+ model, using stand and species parameters gathered from the literature (Arneth et al., 2007; Curtis et al., 2001; Goldstein et al., 1998; Pressely et al., 2006; Waring et al., 1998). Emissions factors were used from a previous modelling study at these sites (Arneth et al., 2007). Meteorological data was gathered using eddy-covariance measurements techniques at each site.

\subsubsection{Site 1}

We used measurements from two field campaigns at two Mediterranean Quercus pubescens stands in southern France $\left(43^{\circ} 39^{\prime} \mathrm{N}, 6^{\circ} \mathrm{E}\right)$ conducted during 2000 and 2001 . In these campaigns, isoprene fluxes were measured with the eddy covariance technique for approximately two weeks in the summer of each year. The fast isoprene sensor (Hills and Zimmerman, 1990) was employed in these measurements, and half hour values were stored. These data have been used to 
examine the diurnal course of emissions predicted by each model. Average diurnal courses were constructed by taking the emission value for each hour of each day.

\subsubsection{Site 2}

To our knowledge, the only available long-term data set of forest eddy-covariance measurements of isoprene emissions is from the University of Michigan Biological Station (UMBS, $45^{\circ} 33^{\prime} \mathrm{N}, 84^{\circ} 43^{\prime} \mathrm{W}$ ), (Pressley et al., 2005; http:// www.biosci.ohio-state.edu/ $\sim$ pcurtis/UMBS $\sim$ Flux). This site supports a mixed forest, dominated by Populus grandidentata, P. tremuloides, Quercus rubra, Fagus grandifolia, Acer rubrum, and Pinus strobus (Curtis et al., 2005; Pressley et al., 2005, 2006). Three years of eddy covariance measurements, from the growing seasons of 2000, 2001, and 2002, are available to test the model efficiency at capturing seasonal time-courses.

\section{Results}

\subsection{Evaluating isoprene model emissions: diurnal time-courses}

The data from the French site were used to test the capacity of the models to reproduce the diurnal time-courses of isoprene emissions. Each model compared well against the average diurnal time-course (Fig. 1). The Guenther et al. model failed to reproduce the midday decline in emissions, and thus, overestimated the emissions at this site. The Martin et al. model also overestimated the midday isoprene emission rate, but to a smaller extent. The Niinemets et al. model accurately reproduced the early morning and late evening emissions, and also gave accurate estimates of the average diurnal midday emissions. When looking at the complete time series, no noticeable differences among model predictions can be discerned, except for the last five days of the measurement campaign in 2001. During this period, a large increase in the emissions was observed, which was accurately reproduced by both the Guenther et al. and the Martin et al. model. The Niinemets et al. model, however, proved unresponsive during this period. This increase in the emissions was correlated with an increase in temperature during the last four days. Over the entire time series, all models performed well with an $r^{2}$ correlation of $0.71,0.74$, and 0.72 for the Guenther et al., Niinemets et al., and Martin et al. models respectively.

Temperature and available light are the two main drivers for each of the models. The Guenther et al. and Martin et al. models showed similar responses to both temperature and radiation in 2001 (Fig. 2). Each showed a non-linear response to temperature with emissions exponentialy increasing with increasing temperature. The Niinemets et al. model was less sensitive to higher temperatures than the other two models (Fig. 2). Each of the models showed a similar response to global radiation (Fig. 2), though the slope of the response differed slightly between models $a=0.015,0.016$, and 0.014 for the Guenther et al., Martin et al., and Niinemets et al. models respectively.

\subsection{Evaluating isoprene model emissions: seasonal time-courses}

The effect of phenological events during spring and autumn was well captured in 2000 and 2001 (Fig. 3). In 2002, the spring emissions were overestimated, though the higher proportion of missing data during this period complicated the comparison. The autumn reduction in isoprene emission was correctly predicted by the models for each year. Day-today variability and summer maxima were reproduced with a lesser accuracy than the long-term phenological effects. In particular, the models strongly underestimated emissions in 2000. The actual data exhibited a larger variability than the models in each year, in particular in 2000 and 2001. Both the Guenther et al. and the Niinemets et al. model showed nonlinear responses in their ability to simulate emissions, accurately capturing low level emissions $\left(\sim<20 \mathrm{mg}_{\mathrm{C}} \mathrm{m}^{-2} \mathrm{~d}^{-1}\right)$, but underestimating higher emissions. The slope of the linear regression of both against the measurements were comparable and reflect this underestimation (Fig. 3). The Martin et al. model showed a more linear response, with a slight tendency to underestimate emissions in all cases. Although the slope of the response of the Martin et al. model was better than that of the other two models, the root mean squared error of the Martin et al. model results was $46 \%$ higher than that of the Guenther et al. model and 30\% higher than that of the Niinemets et al. model.

\subsection{Current emissions from European forests}

Total simulated isoprene emission from pre-enlargement European Union with Norway and Switzerland (EU15+2) was $1.03 \mathrm{TgC} \mathrm{a}^{-1}$ for the period between 1960 and 1990. A broad range of canopy emissions was observed for the species considered (Fig. 4), with order of magnitude differences per unit ground area. However, when considered together with species aerial coverage and climatic distribution, the strongest emitters were not necessarily the largest contributors to the European emission budget. The Europe-wide isoprene emission was dominated by a few species. Quercus robur was by far the highest contributor, with $32 \%$ of total Europe-wide emission. Quercus pubescens and Quercus petraea contributed $18 \%$ and $16 \%$. Eucalyptus species, Quercus frainetto, and Quercus pyrenaica each contributed around $6 \%$ to total emissions. Six species contributed between 1 and 2\% (Quercus faginea, Quercus rubra, Populus spp., Robinia pseudacacia, Picea abies), with the remaining species contributing less than $1 \%$ of the total European emission budget.

Monoterpene emissions showed a similar pattern, with a very broad range of species emissions per unit stand area, 


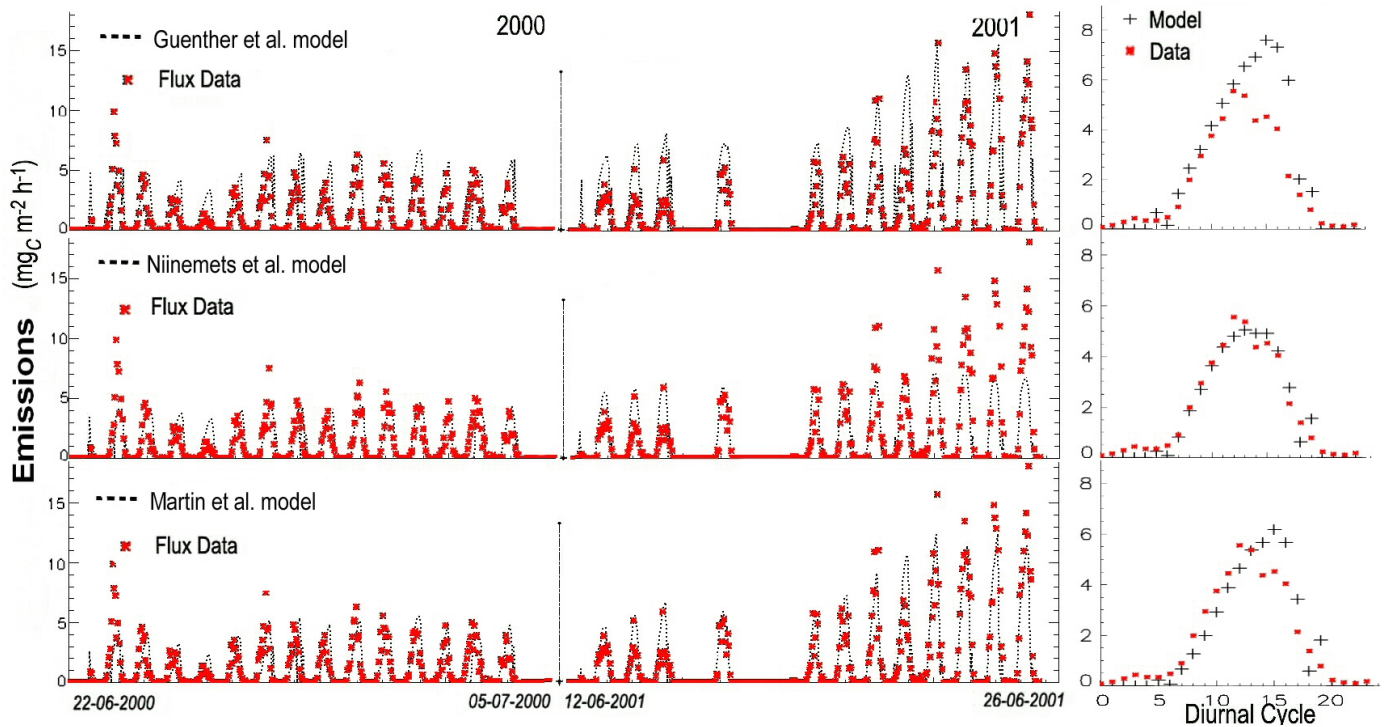

Fig. 1. Hourly measured canopy isoprene emissions $\left(\mathrm{mg}_{\mathrm{C}} \mathrm{m}^{-2} \mathrm{~h}^{-1}\right)$, from the French site for two two-week periods in 2000 and 2001 (Arneth et al., 2007), compared with the simulation results using GOTILWA+ with the three isoprene emission models (Guenther et al., Niinemets et al., and Martin et al. models). The average diurnal time-course from the measurements is also compared with the simulation results.
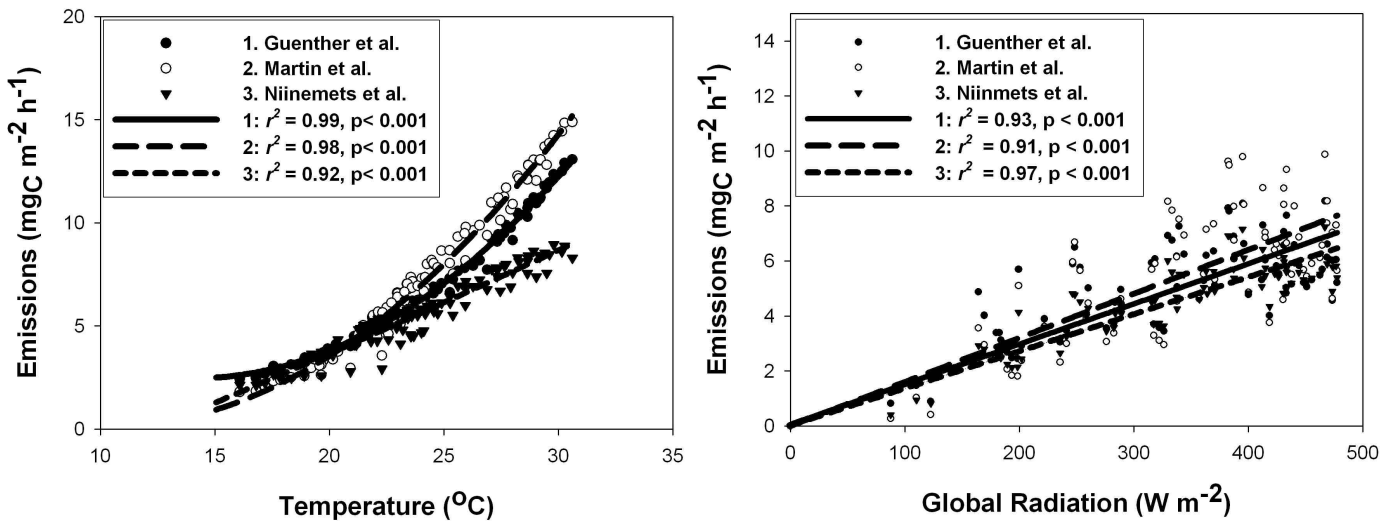

Fig. 2. Temperature $\left({ }^{\circ} \mathrm{C}\right.$, left $)$ and radiation $\left(\mathrm{W} \mathrm{m}^{-2}\right.$, right) responses of hourly simulated canopy isoprene emissions $\left(\mathrm{mg}_{\mathrm{C}} \mathrm{m}^{-2} \mathrm{~h}^{-1}\right)$, from the French site for the two-week period in 2001, for each of the three isoprene emission models (Guenther et al., Martin et al., and Niinemets et al. models). Regressions against temperature are polynomial regressions given by the equation $y=y_{0}+a x+b x^{2}$, whilst regressions against radiation are linear regressions of the form $y=y_{0}+a x$, with a root mean squared error of the regressions of - Temperature: $2.7,3.5,1.8$ and Radiation: 2.5, 2.8, 2.3 for the Guenther et al., Martin et al., and Niinemets et al. models, respectively.

but with only a few species dominating the total budget of emissions from European forests when both emission potentials and geographical distribution were taken into account. Total simulated emissions amounted to $0.93 \mathrm{TgC} \mathrm{a}^{-1}$. Of this total, 24\% was emitted by forests dominated by Quercus ilex, $21.5 \%$ by Pinus sylvestris, $16 \%$ by Fagus sylvatica, $11 \%$ by Picea abies and $7 \%$ by Quercus suber. Seven further forest species (Fig. 5) contributed between 1 and 2\% to total emissions, with the remaining forest species contributing less than $1 \%$.
Emissions showed a strong regional pattern, being influenced by the distribution of the species across Europe, and regional weather patterns. For isoprene emission, France showed the highest emissions for the period 1960-1990 (Fig. 6), followed by the north-western area of the Iberian Peninsula. The Mediterranean zone, although it is subject to higher temperatures, and radiation, showed lower emissions than central mainland Europe due to lower plant coverage and leaf area index as well as due to suppression of emissions during extensive summer drought periods (as reported by e.g. Grote et al., 2009). 


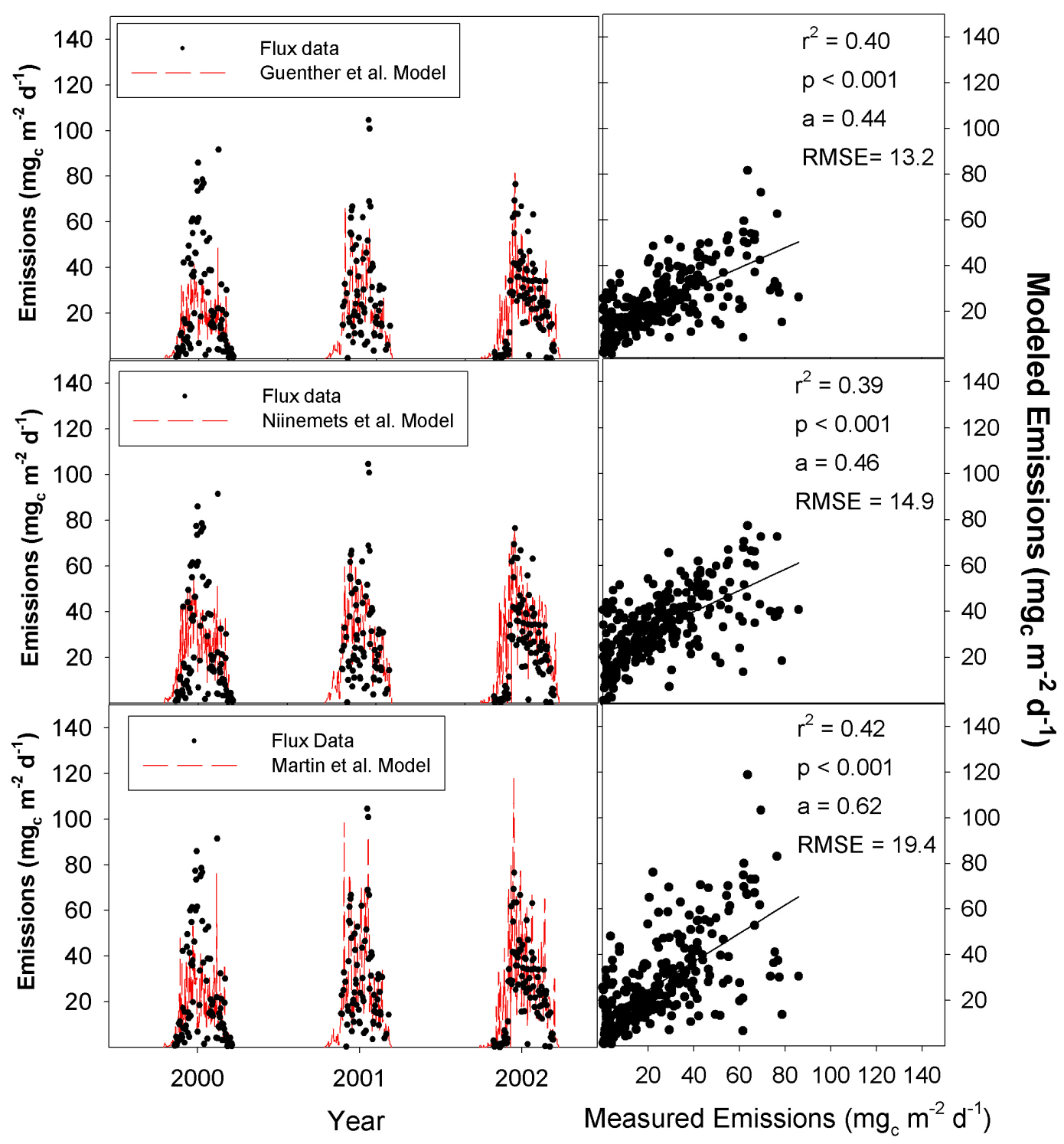

Fig. 3. Comparison of daily integrated canopy isoprene emission fluxes from the UMBS forest (Pressley et al., 2005) and fluxes simulated by GOTILWA+ with the three emission models compared (Guenther et al., Martin et al., and Niinemets et al. models) over three years (left panels) and the regressions of measurements vs. simulations (right panels). $a$ represents the slope of the presented linear regressions, and RMSE is the root mean squared error.

Simulated monoterpene emissions were lower than those of isoprene, with lower interspecific emission rate variability. The emissions of monoterpenes also showed a more uniform spatial distribution. The highest emissions were predicted for the southern Iberian Peninsula, and areas of the Mediterranean zone (Fig. 7).

\subsection{Model comparisons for the period 1960-1990}

The period 1960-1990 is often used as a baseline for comparing regional models in the past and the future (Schröter et al., 2005). For isoprene, slight differences were observed between the emission model predictions for this period, with the Guenther et al. and Martin et al. models giving $8.8 \%$ and $6.1 \%$ higher emissions than the Niinemets et al. model. For monoterpenes, the Guenther et al. model gave slightly higher (4.6\%) emissions than the Niinemets et al. model for the simulated period, perhaps due to a slightly stronger temperature response (Arneth et al., 2007).

\subsection{Projected future European emissions}

Although the choice of the model had little effect on the estimated budget of isoprenoids during the period 1960-1990, 


\section{Isoprene Emissions}

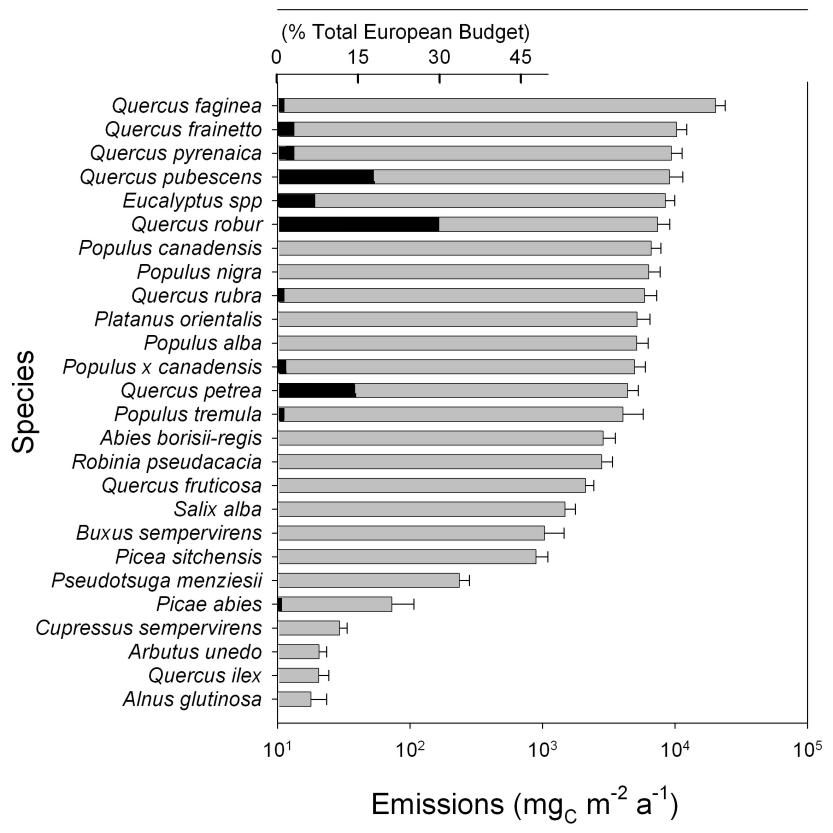

Fig. 4. Estimated average annual isoprene emissions (log scale) from European forest species for the period 1960-1990 (grey bars). Values represent average estimates from the three emissions models (Guenther et al., Niinemets et al., and Martin et al.). Black bars denote the percent contribution of each species to the total European isoprene emissions budget for this period (for contributions of greater than 1\%). Error bars represent the spatial standard deviation from the mean for the model ensemble. Species emission potentials are according to Table 1.

projected future emission estimates were greatly affected by the choice of the emission model. In the case of isoprene, the models showed up to a two-fold difference in predicted emission rates by 2100 (Fig. 8). Differences were not fully evident until about 2050, when large disparities began to appear between the models. All models agreed on a general strong increasing trend in both isoprene and monoterpene emissions, though the dynamics of this trend differed between models. For isoprene emission, the Martin et al. model showed the strongest response with average per pixel emission of $4400 \mathrm{mg}_{\mathrm{C}} \mathrm{m}^{-2} \mathrm{a}^{-1}$ from European forests. This gave a total European budget of $2.36 \mathrm{TgC} \mathrm{a}^{-1}$ for the period 2080 2100 , i.e. more than double the average emission predicted for the period 1960-1990 with the same model. The Guenther et al. model gave slightly higher emissions than the other models for the early 21 st century, but did not respond as strongly as the Martin et al. model under conditions of more severe climate change $\left(3720 \mathrm{mg}_{\mathrm{C}} \mathrm{m}^{-2} \mathrm{a}^{-1}\right.$ for $2080-2100$ ). Total European isoprene emission simulated with the Guenther et al. model for the period $2080-2100$ was $2 \mathrm{TgC} \mathrm{a}^{-1}$. The Niinemets et al. model predicted the lowest emission of the three models throughout the century, and did not respond

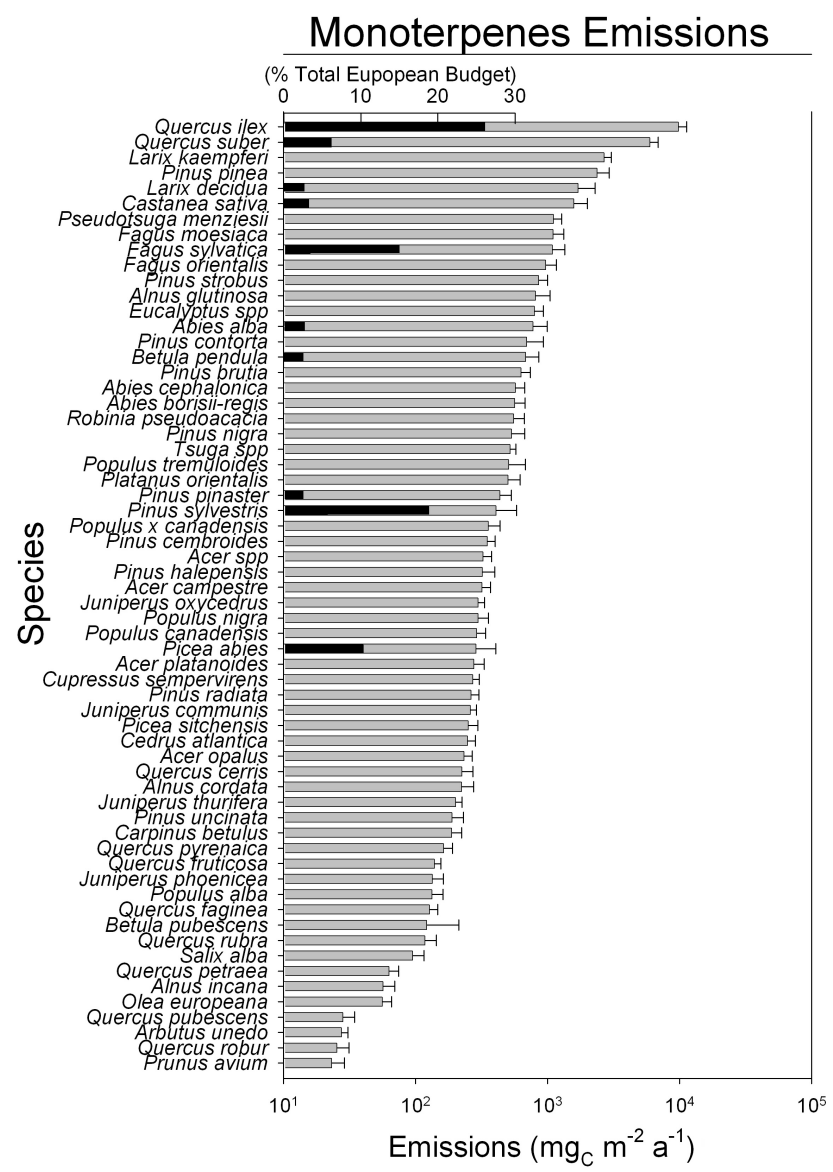

Fig. 5. Estimated average annual monoterpene emissions $\left(\mathrm{mg}_{\mathrm{C}} \mathrm{m}^{-2} \mathrm{a}^{-1}\right)$ from European forest species for the period 1960 1990 (grey bars). Values represent average estimates from the two emissions models (Guenther et al., and Niinemets et al.). Black bars denote the percent contribution to total European monoterpene emissions budget for this period (for contributions of greater than $1 \%$ ). Error bars represent the spatial standard deviation from the mean for the model ensemble. Species emission potentials follow Table 1.

as strongly as the other models to future climate change, giving a total of $1.58 \mathrm{TgC} \mathrm{a}^{-1}$. On average, $98 \%$ increase in isoprene emission was predicted for the period 2080-2100 relative to the emission in the period 1960-1990 with the three emission models.

Of the two monoterpene emission models, the Guenther et al. model consistently predicted higher emissions than the Niinemets et al. model throughout the 21 st century, and responded much more strongly to climate change, perhaps reflecting its higher temperature sensitivity as suggested by $\mathrm{Ar}$ neth et al. (2007). For the period between 2080 and 2100, the Guenther et al. model predicted a total European monoterpene budget of $1.27 \mathrm{TgCa}^{-1}$, which represents a $31 \%$ increase in monoterpene emissions with respect to the emissions for the period 1960-1990. The Niinemets et al. model predicted a smaller increase in the emissions, giving a total 


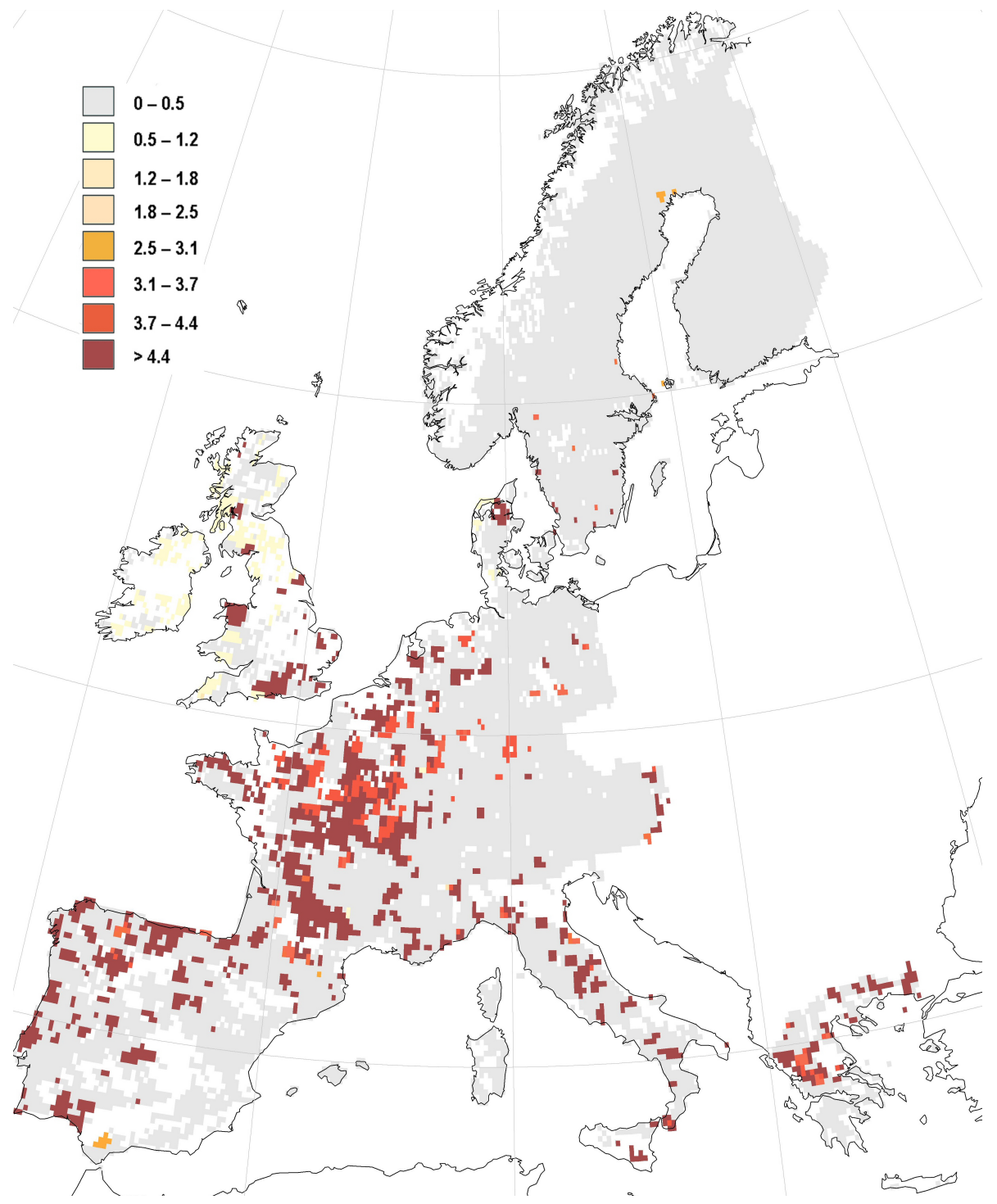

Fig. 6. Estimated annual isoprene emissions $\left(\mathrm{gC} \mathrm{m}^{-2} \mathrm{a}^{-1}\right)$ from European forests over the period 1960-1990, using average estimates from the three isoprene emissions models coupled to GOTILWA+.

emission from European forests of $1.07 \mathrm{TgC} \mathrm{a}^{-1}$, which represented an $11 \%$ increase with respect to the period from 1960 to 1990 . As an average of the two models, monoterpene emissions from European forests were predicted to increase by $21 \%$ for the period $2080-2100$ relative to the period 1960-1990.

\section{Discussion}

To our knowledge, this is the first time different BVOC emission modelling approaches have been run in parallel on a regional scale. The results serve to both reduce and highlight uncertainty in the modelling of current emissions of isoprene and monoterpenes from European forest species through a two-pronged approach: the compilation and assessment of species specific emission potentials, addressing the broad variability of values published in the literature, and the comparison of three distinct methodologies for the prediction of regional emissions.

So far, all regional emission inventories in Europe have been based on uncritical use of species emission potentials collected in databases that have not been updated since late 90s (e.g., Nick Hewitt's database: http://www.es.lancs.ac.uk/ cnhgroup/iso-emissions.pdf) (Parra et al., 2004; Projections, 2007; Simpson et al., 1999; Solmon et al., 2004). However, new information has become available on the emission characteristics of some important species such as important Mediterranean species Quercus suber that has been traditionally considered "non-emitting" species in emission 


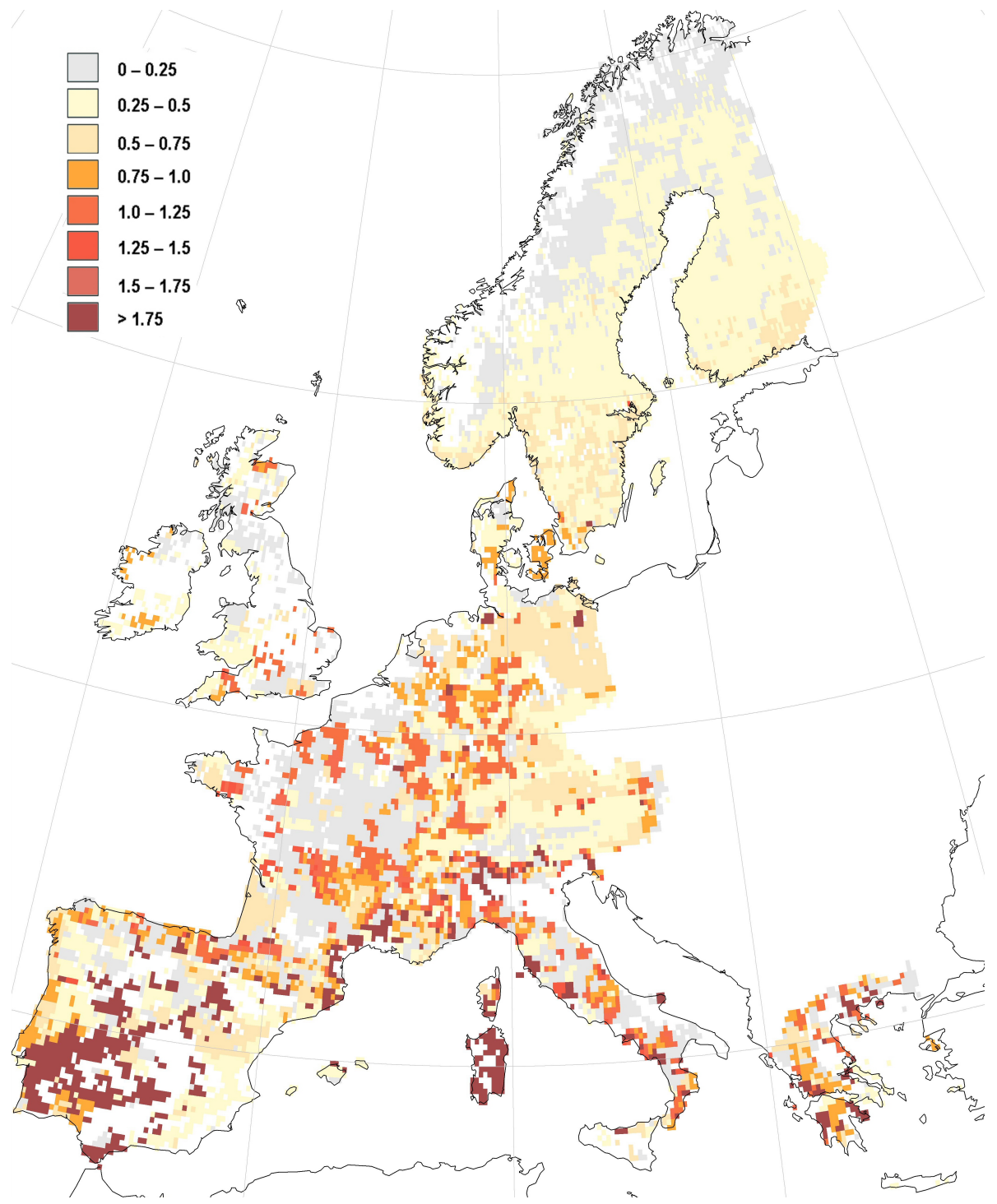

Fig. 7. Estimated annual monoterpene emissions $\left(\mathrm{gC} \mathrm{m}^{-2} \mathrm{a}^{-1}\right)$ from European forest canopies over the period 1960-1990, using average estimates from the two monoterpene emission models (Guenther et al. and Niinemets et al.) coupled to GOTILWA+.

models. Recent data show that this species strongly emits monoterpenes (Pio et al., 2005; Staudt et al., 2004). Analogously, Fagus sylvatica, a dominant component in European temperate deciduous forests has previously been reported to be a minute monoterpene emitter (König et al., 1995; Steinbrecher et al., 1993), while recent data demonstrated that this species is moderate to high monoterpene emitter (Dindorf et al., 2006; Luchetta, 1999; Moukhtar et al., 2005). While for some species, reliable information of emission potentials is still not available, the aerial coverage of these species is generally small and only minor improvement of large-scale emission estimates is expected.

Model comparisons with tower flux measurements at midlatitude forest sites show that the models do not differ greatly in their ability to reproduce the short-term variations in iso- prene emission, accurately capturing the diurnal time-course of isoprene emission driven by modifications in light and temperature. The Guenther et al. model, being solely based on light and temperature, was not effective at capturing the mid-day decline in the emission in drought conditions, leading to a general overestimation of the total emission at the Mediterranean site. The Guenther et al. model is based on two driving variables, and assumes a fixed shape of the response of isoprene emission to these variables. Yet, other factors have been known to affect the emission rates as well (e.g., Affek and Yakir, 2002; Loreto et al., 2001; Loreto and Velikova, 2001; Peñuelas and Llusia, 2001; Sharkey and Singsaas, 1995; Sharkey and Yeh, 2001). Given its simplicity, its performance under present-day conditions is surprisingly comparable with the other two more plastic models. 

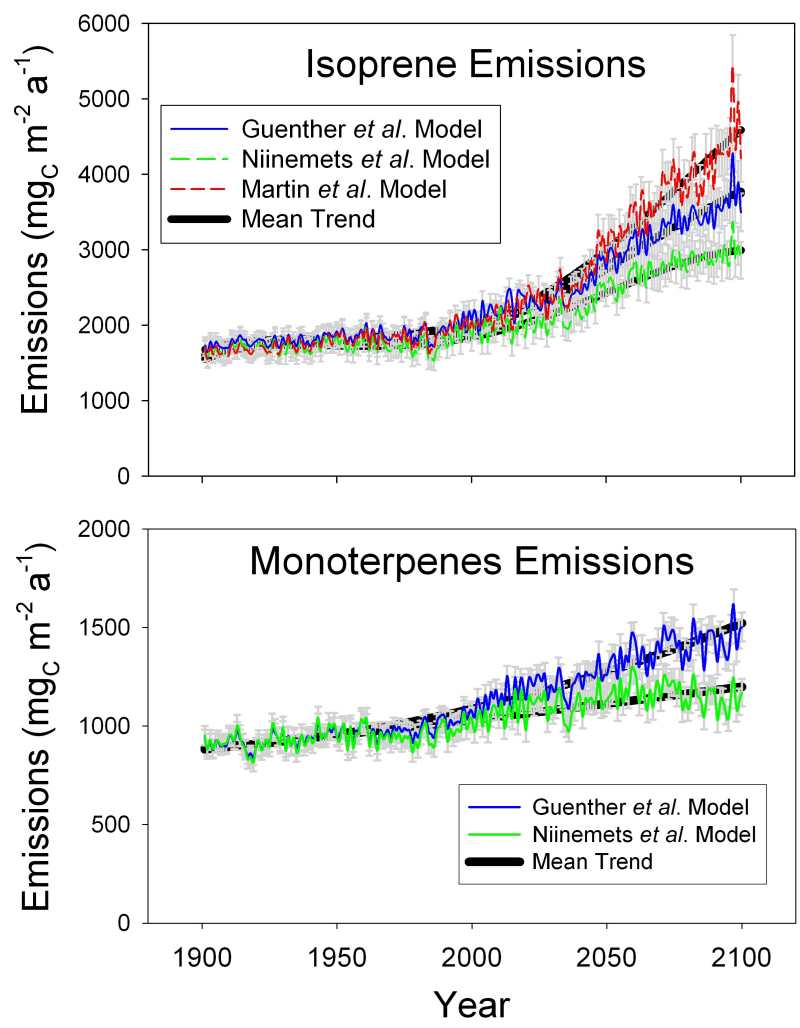

Fig. 8. Average per $\mathrm{m}^{2}$ modelled isoprene and monoterpenes emissions from European forest canopies from 1900 to 2100. Climate from the CRU (New et al., 1999) was used for the period 1900 to 2000. Results from 2001 to 2100 correspond to climate from HadCM3 global circulation model using climate change scenario A2 (IPCC, 2001, 2007). The displayed error bars (in grey) represent the standard error from the mean due to spatial variation. The Mean Trend is a quadratic regression $\left(y=y_{0}+a x+b x^{2}\right)$ of the displayed data.

The Niinemets et al. model performed better for simulation of average diurnal emission time-course, but it was unresponsive to the high temperatures experienced in the last few days at the French site. The response of the Niinemets et al. model to temperature was reported in a previous study (Arneth et al., 2007, Fig. 1), though not discussed in detail. There, it was also shown to be slightly less responsive to temperature than the other two models. The mid-day decline of the Niinemets et al. model is related to its stronger dependence on light through the electron transport activity (Arneth et al., 2007). As numerous studies investigating diurnal variations in chlorophyll fluorescence in drought-stressed plants demonstrate, electron transport activity is also downregulated around mid-day, in line with the rates of photosynthesis. In addition, the model of Niinemets et al. based on overall energy level predicts that the mid-day decline is associated in downregulation of DMADP pool size (that is linked to the rate of electron transport). Recent support to this hypothesis comes from the study of Magel et al. (2006). The Martin et al. model, which takes a more detailed approach to describe the limiting precursors of emissions, better reproduced the diurnal time-series, accurately capturing both the day-to-day variability and the average diurnal time-course. Long-term (daily to seasonal) emissions were moderately well reproduced by the models. The low correlation with the data highlights the fact that a complete understanding of emissions drivers and controls is missing from the models, and we are indeed a long way from fully realistic BVOC emission estimates (Arneth et al., 2008b; Grote and Niinemets, 2008; Monson et al., 2007).

The analysis of the models diurnal responses to light and temperature (Fig. 2) suggests that the temperature response is responsible for most of the model differences. This became more apparent at higher temperatures, and explains the increasing differences between model predictions as we move to a projected future warmer climate. Resolving this temperature response will be one of the challanges for future VOC modelling studies. More long term measurements of emissions data from forest canopies in regions which experience high summer temperatures would be of great benefit.

Although there are many strong isoprene and monoterpene emitting tree species in Europe, the regional distribution of these species leads to only a few of these strong emitters being important for the estimation of total European emission budget. These species were not necessarily the strongest emitters, but tended to be species with large coverage in regions with high temperatures and radiation. Total European forest isoprene emissions for the late 20th century were strongly dominated by three Quercus species, making up over two thirds of the total isoprene emission. It is therefore of considerable importance to focus research efforts on accurately quantifying the emission potentials from these species, and their emission responses to environmental drivers. Monoterpene emissions were similarly dominated by a few species, with five species contributing $80 \%$ of the total emission budget. Having more accurate data on these species could greatly improve the reliability of estimates of present day emission budgets. This dominance of few species over the total European emissions budget means that the use of an improved basal emissions database did not lead to a large difference in the total budget when compared to previous studies. We expect, however, that local budgets should be improved by the use of a more up to date basal emissions database. As we have confirmed the total budget using more rigorous methods, we can also have more confidence in current model predictions.

The resulting inventory of isoprene emission is similar to the value presented by Simpson et al. (1999) $\left(1.4 \mathrm{TgCa}^{-1}\right.$; Simpson et al., Table 18), and Arneth et al. (2008a, $1.2 \mathrm{TgCa}^{-1}$ ) for the same area. Since isoprene emission estimates are highly uncertain, due to their linear dependency on the leaf emission potentials assigned to a species or vegetation type, and due to strong dependence on the kind and 
quality of the land cover information used (Guenther et al., 2006), the similarity of the calculated annual totals is remarkable. Recently it has been suggested that such agreement between model simulations is due to compensation efforts applied to move model estimates closer to the hypothetical "real" regional or global emission value (Arneth et al., 2008b). We made no such effort, and would suggest that the similarity of different modelled isoprene estimates derives from the fact that regional isoprene emissions are dominated by a few highly emitting and well documented species.

Such similarities do not apply for monoterpene emission estimates, with a broad range of global emissions reported in the literature (Adams et al., 2001; Guenther et al., 1995; Kaplan et al., 2006; Lathiere et al., 2006; Levis et al., 1999; Naik et al., 2004; Tao and Jain, 2005; Valdes et al., 2005). Our estimate of total monoterpene emissions from the European forests of $0.97 \mathrm{TgCa}^{-1}$ is lower than the emission estimate published in Tao and Jain $\left(2005 ; 1.73 \mathrm{TgCa}^{-1}\right)$. However, their simulation is based on a larger part of Europe than ours, and their parameterization also differs from ours by considering six plant functional types only, rather than species-specific parameterization. To our knowledge, no study has simulated the emission of monoterpenes from European forests on a European scale.

Phenology is becomming increasingly recognised to have a strong affect on regional emissions (e.g., Simon et al., 2006; Tarvainen et al., 2007). Here we have applied a simple function to the basal emission potential in order to simulate a common phenological response in each of the models. Such functions have recently been highlighted as one of the biggest uncertainties in regional modelling (Keenan et al., 2009). The extrapolation of phenological functions to the future is also subject to great uncertainty. Most current phenological models predict a lenghtening of the growing season in Europe due to projected future climatic change. This would acount for some of the future increase in emissions reported in this study, but would not lead to between model differences in estimated emissions.

Although both the isoprene and monoterpene emission models performed comparably under current climatic conditions, large differences were observed in the emission estimates for realistic future climatic change scenarios. The differences observed here between model responses for the late 21 st century result from the small differences in temperature, radiation and atmospheric $\mathrm{CO}_{2}$ concentration responses reported in the isoprene model (Arneth et al., 2007, Fig. 1, 2 for review). The isoprene model of Martin et al. is more sensitive to temperature, followed in sensitivity by the Guenther et al. model (Fig. 2). The long-term simulations under gradually increasing temperature and atmospheric $\mathrm{CO}_{2}$ (Fig. 8) highlight the implications of such differences in sensitivities between models. Our study demonstrates that the choice of the model used can greatly alter the final result. The nonconcurrence of the emission models in simulations of future scenarios calls into question the validity of numerous conclu- sions regarding future emissions, and the resulting effects on atmospheric chemistry, made so far on the basis of only one emission model.

A recent study hypothesised that we are overconfident about our ability to accurately model BVOC emissions from terrestrial vegetation, and, according to the terminology of Le Quere (2006), we are in the "illusion" phase of model development (Arneth et al., 2008b). When we consider the estimates of present day emissions that were obtained by applying the same methodology and with the models coupled to the same terrestrial vegetation model, the comparability of model performance does not seem to support such a conclusion. However, when moving to projected future climatic conditions, it becomes clear that we are far from reaching a clear understanding of the processes governing emission rates (Monson et al., 2007), and their potential responses to future climate change.

Current model development efforts are focused on the improvement of simple empirical algorithms (Guenther et al., 2006) and the development of more process-based emission models (Arneth et al., 2006; Back et al., 2005; Grote et al., 2006; Niinemets et al., 2002a; Martin et al., 2000; Niinemets et al., 1999; Zimmer et al., 2000). Each approach lends itself more easily to different applications, such as the easy implication of simple empirical models in atmospheric chemistry models (e.g., Guenther et al., 2006), or the detailed study allowed for by the more intricate models (e.g., Grote et al., 2006). Despite the big differences in model structures, none of the models included in this study outperformed the others. In fact, no existing approach has been shown to perform consistently better (Arneth et al., 2007). This is due both to a lack of detailed model inter-comparisons, and a lack of good quality data with which to test the models. Further efforts in both fields, together with the development of new modelling approaches and synergies (Grote and Niinemets, 2008; Monson et al., 2007) will be needed to advance our ability to reliably simulate emissions. Meanwhile, we urge that results from different model approaches should be considered in any simulation project dealing with terrestrial emissions of BVOCs, particularly if considering future climate change scenarios.

\section{Conclusions}

The coupling of the three different model approaches (The Guenther et al., Niinemets et al. and Martin et al. models) to an ecophysiological forest model provides a unique opportunity to explore the time-dependent changes in modelled biogenic emissions due to differences in model structure and model responses to changes in climatic and physiological processes. The modelled emissions from present day European forests were shown to be independent of the emission model used, with estimates of $1.03 \mathrm{TgC} \mathrm{a}^{-1}$ for 
isoprene emission and $0.93 \mathrm{TgC} \mathrm{a}^{-1}$ for monoterpenes, giving a consistent emission inventory for BVOCs from European forests.

Coincidence of model estimates of emissions for current and past climatic conditions in Europe suggest that the present day inventories of BVOC emissions provide realistic estimates. However, model-dependent differences in simulated estimates of future emissions of both isoprene and monoterpenes highlight the fact that we are in the early stages of the path towards a full understanding of the processes governing BVOC emissions. This has important implications for any study seeking to model future BVOC emissions. Many studies involving modelled future BVOC emissions (e.g., potential offsetting of emissions by rising $\mathrm{CO}_{2}$ concentrations, relative effects of changes in land use on quantitative emission estimates, effects on future emissions on tropospheric $\mathrm{O}_{3}$ concentrations and air quality) may need to be revised to take into account the inherent variability introduced by the choice of the emission model used.

Acknowledgements. This study was funded through the GREENCYCLES Marie-Curie Biogeochemistry and Climate Change Research and Training Network (MRTN-CT-2004-512464) supported by the European Commission's Sixth Framework program. Data was supplied by the ALARM (Assessing LArge-scale environmental Risks for biodiversity with tested Methods: GOCECT-2003-506675) and ATEAM (Advanced Terrestrial Ecosystem Analysis and Modelling: EVK2-2000-00075) project, from the EU Fifth Framework for Energy, Environment and Sustainable Development and the CSIC-Estonian Academy of Sciences collaborative project. TK acknowledges further support from the CCTAME (Climate Change - Terrestrial Adaptation and Mitigation in Europe, FP7 212535) project. JP acknowledges additional funding from the Spanish Ministry of Education and Science project (CGL2006-04025), Consolider Montes (CSD2008-00040), and a Catalan Government project grant (SGR2008-00312) and ÜN from the Estonian Science Foundation (Grant 7645) and the Estonian Ministry of Education and Science (Grant SF1090065s07). Comments from two anonymous referees are also gratefully acknowledged. Shelley Pressley and Dominic Serca are kindly thanked for providing field flux measurements. Computational resources used in this work were kindly provided by the Oliba Project of the Universitat Autonoma de Barcelona.

Edited by: T. Karl

\section{References}

Adams, J. M., Constable, J. V. H., Guenther, A. B., and Zimmerman, P.: An estimate of natural volatile organic compound emissions from vegetation since the last glacial maximum, Chemosphere, 3, 73-91, 2001.

Andrews, T. J. and Kane, H. J.: Pyruvate as a by-product of catalysis by ribulosebisphosphate carboxylase/oxygenase, J. Biol. Chem., 266, 9447-9452, 1991.

Arey, J., Winer, A., Atkinson, R., Aschmann, S. M., Long, W. D., and Morrison, C. L.: The emission of (Z)-3-hexen-1-ol, (Z)-3- hexenylacetate and other oxygenated hydrocarbons from agricultural plant species, Atmos. Environ., 25A, 1063-1075, 1991a.

Arey, J., Winer, A. M., Atkinson, R., Aschmann, S. M., Long, W. D., Morrison, C. L., and Olszyk, D. M.: Terpenes emitted from agricultural species found in California's Central Valley, J. Geophys. Res.-Atmos., 96, 9329-9336, 1991 b.

Arneth, A., Niinemets, Ü., Pressley, S., Bäck, J., Hari, P., Karl, T., Noe, S., Prentice, I. C., Serça, D., Hickler, T., Wolf, A., and Smith, B.: Process-based estimates of terrestrial ecosystem isoprene emissions: incorporating the effects of a direct $\mathrm{CO}_{2}$ isoprene interaction, Atmos. Chem. Phys., 7, 31-53, 2007, http://www.atmos-chem-phys.net/7/31/2007/.

Arneth, A., Schurgers, G., Hickler, T., and Miller, P. A.: Effects of species composition, land surface cover, $\mathrm{CO}_{2}$ concentration and climate on isoprene emissions from European forests, Plant Biology, 10, 150-162, 2008a.

Arneth, A., Monson, R. K., Schurgers, G., Niinemets, Ü., and Palmer, P. I.: Why are estimates of global terrestrial isoprene emissions so similar (and why is this not so for monoterpenes)? Atmos. Chem. Phys., 8, 4605-4620, 2008b, http://www.atmos-chem-phys.net/8/4605/2008/.

Affek H. P. and Yakir D.: Protection by isoprene against singlet oxygen in leaves, Plant Physiol., 129, 269-277, 2002.

Bäck, J., Hari, P., Hakola, H., Juurola, E., and Kulmala, M.: Dynamics of monoterpene emissions in Pinus sylvestris during early spring, Boreal Environ. Res., 10, 409-424, 2005.

Bai, J., Baker, B., Liang, B., Greenberg, J., and Guenther A.: Isoprene and monoterpene emissions from an Inner Mongolia grassland, Atmos. Environ., 40, 5753-5758, 2006.

Baldocchi, D. D., Fuentes, J. D., Bowling, D. R., Turnipseed, A. A., and Monson, R. K.: Scaling isoprene fluxes from leaves to canopies: test cases over a boreal aspen and a mixed species temperate forest, J. Appl. Meteorol., 38, 885-898, 1999.

Ball, J. T., Woodrow, I. E., and Berry, J. A.: A model predicting stomatal conductance and its contribution to the control of photosynthesis under different environmental conditions, in: Progress in photosynthesis research. Proc. VII Int. Photosynthesis congress, edited by: Biggens, J., Martinus Nijhoff Publishers, Dordrecht, 221-224, 1987.

Bell, M. and Ellis, J. E.: Sensitivity analysis of tropospheric ozone to modified biogenic emissions for the Mid-Atlantic region, Atmos. Environ., 38, 1879-1889, 2004.

Benjamin, M. T., Sudol, M., Bloch, L., and Winer, A. M.: Lowemitting urban forests: a taxonomic methodology for assigning isoprene and monoterpene emission rates, Atmos. Environ., 30, 1437-1452, 1996.

Benjamin, M. T. and Winer, A. M.: Estimating the ozone-forming potential of urban trees and shrubs, Atmos. Environ., 32, 53-68, 1998.

Bertin, N. and Staudt, M.: Effect of water stress on monoterpene emissions from young potted holm oak (Quercus ilex L.) trees, Oecologia, 107, 456-462, 1996.

Bertin, N., Staudt, M., Hansen, U., Seufert, G., Ciccioli, P., Foster, P., Fugit, J. L., and Torres, L.: Diurnal and seasonal course of monoterpene emissions from Quercus ilex (L.) under natural conditions - applications of light and temperature algorithms, Atmos. Environ., 31, 135-144, 1997.

Brilli, F., Barta, C., Fortunati, A., Lerdau, M., Loreto, F., and Centritto, M.: Response of isoprene emission and carbon metabolism 
to drought in white poplar (Populus alba) saplings, New Phytol., 175, 244-254, 2007.

Broecking, C. D. and Salom, S. M.: Volatile emissions of eastern hemlock, Tsuga canadensis, and the influence of hemlock woolly adelgid, Phytochemistry, 62, 175-180, 2003.

Brüggemann, N. and Schnitzler, J.-P.: Comparison of isoprene emission, intercellular isoprene concentration and photosynthetic performance in water-limited oak (Quercus pubescens Willd. and Quercus robur L.) saplings, Plant Biology, 4, 456463, 2002.

Businger, J. A. and Oncley, S. P.: Flux Measurement with Conditional Sampling, J. Ocean. Atmos. Tech., 7, 349-352, 1990.

Campbell, G. S.: Extinction coefficients for radiation in plant canopies calculated using an ellipsoidal inclination angle distribution, Agric. Forest Meteorol., 36, 317-321, 1986.

Campbell, G. S.: Derivation of an angle density function for canopies with ellipsoidal leaf angle distribution, Agric. Forest Meteorol., 49, 173-176, 1990.

Ciccioli, P., Brancaleoni, E., Frattoni, M., Marta, S., Brachetti, A., Vitullo, M., Tirone, G., and Valentini, R.: Relaxed eddy accumulation, a new technique for measuring emission and deposition fluxes of volatile organic compounds by capillary gas chromatography and mass spectrometry, J. Chromatogr. A., 985, 283-296, 2003.

Ciccioli, P., Fabozzi, C., Brancaleoni, E., Cecinato, A., Frattoni, M., Loreto, F., Kesselmeier, J., Schäfer, L., Bode, K., Torres, L., and Fugit, J.-L.: Use of the isoprene algorithm for predicting the monoterpene emission from the Mediterranean holm oak Quercus ilex L.: performance and limits of this approach, J. Geophys. Res., 102, 23319-23328, 1997.

Collins, W., Derwent, R. G., Johnson, C. E., and Stevenson, D. S.: The oxidation of organic compounds in the troposphere and their global warming potentials, Climatic Change, 52, 453-479, 2004.

Copolovici, L., Filella, I., Llusia, J., Niinemets, Ü., and Peñuelas, J.: The capacity for thermal protection of photosynthetic electron transport varies for different monoterpenes in Quercus ilex, Plant Physiol., 139, 485-496, 2005.

Corchnoy, S. B., Arey, J., and Atkinson, R.: Hydrocarbon emissions from twelve urban shade trees of Los Angeles, California, air basin, Atmos. Environ., 26, 339-348, 1992.

Curtis, P. S., Vogel, C. S., Gough, C. M., Schmid, H. P., Su, H. B., and Bovard, B. D.: Respiratory carbon losses and the carbon use efficiency of a northern hardwood forest, 1999-2003, New Phytol., 167, 437-456, 2005.

Csiky, O. and Seufert, G.: Terpenoid emissions of Mediterranean oaks and their relation to taxonomy, Ecol. Appl., 9, 1138-1146, 1999.

Dai, Y. J., Dickinson, R. E., and Wang, Y. P.: A two-big-leaf model for canopy temperature, photosynthesis, and stomatal conductance, J. Climate, 17, 2281-2299, 2004

Dindorf, T., Kuhn, U., Ganzeveld, L., Schebeske, G., Ciccioli, P., Holzke, C., Köble, R., Seufert, G., and Kesselmeier, J.: Significant light and temperature dependent monoterpene emissions from European beech (Fagus sylvatica L.) and their potential impact on the European volatile organic compound budget, J. Geophys. Res.-Atmos., 111, D16305, doi:16310.11029/12005JD006751, 2006.

Drewitt, G. B., Curren, K., Steyn, D. G., Gillesspie, T. J., and Niki, H.: Measurement of biogenic hydrocarbon emissions from veg- etation in the lower Fraser Valley, British Columbia, Atmos. Environ., 32, 3457-3466, 1998.

Dutaur, L.: Caractérisation des sources biogéniques descomposés organiques volatils contribuant à la pollution photochimique dans le bassin méditerranéen. PhD Thesis, Institut National Polytechnique Toulouse, France, Toulouse, 1996.

Duyzer, J.: Measurements of the emissions of monoterpenes from Douglas fir forest, Tech. Rep. IMW-R 93/312, TNO Inst. Environ. Energy Technol., Delft, 1993.

Evans, R. C., Tingey, D. T., Gumpertz, M. L., and Burns, W. F.: Estimates of isoprene and monoterpene emission rates in plants, Botanical Gazette, 143, 304-310, 1982.

Fall, R. and Wildermuth, M. C.: Isoprene synthase: from biochemical mechanism to emission algorithm, J. Geophys. Res., 103, 25599-25609, 1998.

Fares, S., Barta, C., Brilli, F., Centritto, M., Ederli, L., Ferranti, F., Pasqualini, S., Reale, L., Tricoli, D., and Loreto, F.: Impact of high ozone on isoprene emission, photosynthesis and histology of developing Populus alba leaves directly or indirectly exposed to the pollutant, Physiol. Plantarum, 128, 456-465, 2006.

Farquhar, G. D., von Caemmerer, S., and Berry, J. A.: A biochemical model of photosynthetic $\mathrm{CO}_{2}$ assimilation in leaves of $\mathrm{C}_{3}$ species, Planta, 149, 78-90, 1980.

Fehsenfeld, F., Calvert, J., Fall, R., Goldan, P., Guenther, A., Hewitt, C. N., Lamb, B., Liu, S., Trainer, M., Westberg, H., and Zimmerman, P.: Emissions of volatile organic compounds from vegetation and the implications for atmospheric chemistry, Global Biogeochem. Cy., 6, 389-430, 1992.

Flyckt, D. L.: Seasonal variation in the volatile hydrocarbon emissions from ponderosa pine and red oak, MSc Thesis, Washington State University, Pullman, Washington, USA, 1979.

Flyckt, D. L., Westberg, H. H., and Holdren, M. W.: Natural organic emissions and their impact on air quality. Presentation to 73rd annual meeting of the Air Pollution Control Association, Montreal, Canada, Washington State University, Pullman, 1980.

Fuentes, J. D., Lerdau, M., Atkinson, R., Baldocchi, D., Bottenheim, J. W., Ciccioli, P., Lamb, B., Geron, C., Gu, L., Guenther, A., Sharkey, T. D., and Stockwell, W.: Biogenic hydrocarbons in the atmosphere boundary layer: a review, B. Am. Meteorol. Soc., 81, 1537-1575, 2000.

Fuentes, J. D. and Wang, D.: On the seasonality of isoprene emissions from a mixed temperate forest, Ecol. Appl., 9, 1118-1131, 1999.

Funk, J. L., Giardina, C. P., Knohl, A., and Lerdau, M. T.: Influence of nutrient availability, stand age, and canopy structure on isoprene flux in a Eucalyptus saligna experimental forest, J. Geophys. Res.-Biogeosci., 111, G02012, doi:10.1029/2005JG000085, 2006.

Gelencsçer, A., May, B., Simpson, D., Sçanchez-Ochoa, A., Kasper-Giebl, A., Puxbaum, H., Caseiro, A., Pio, C., and Legrand, M.: Source apportionment of PM2.5 organic aerosol over Europe: Primary/secondary, natural/anthropogenic, and fossil/biogenic origin, J. Geophys. Res., 112, D23S04, doi:10.1029/2006JD008094, 2007.

Geron, C., Guenther, A., Greenberg, J., Loescher, H. W., Clark, D., and Baker, B.: Biogenic volatile organic compound emissions from a lowland tropical wet forest in Costa Rica, Atmos. Environ., 36, 3793-3802, 2002.

Geron, C. D., Guenther, A. B., and Pierce, T. E.: An improved 
model for estimating emissions of volatile organic compounds from forests in the eastern United States, J. Geophys. Res., 99, 12773-12791, 1994.

Geron, C., Guenther, A., Sharkey, T. D., and Arnts, R. R.: Temporal variability in basal isoprene emission factor, Tree Physiol., 20, 799-805, 2000.

Goldstein, A. H., Goulden, M. L., Munger, J. W., Wofsy, S. C., and Geron, C. D.: Seasonal course of isoprene emissions from a midlatitude deciduous forest, J. Geophys. Res., 103, 3104531056, 1998.

Geron, C., Harley, P., and Guenther, A.: Isoprene emission capacity for US tree species, Atmos. Environ., 35, 3341-3352, 2001.

Grabmer, W., Kreuzwieser, J., Wisthaler, A., Cojocariu, C., Graus, M., Rennenberg, H., Steigner, D., Steinbrecher, R., and Hansel, A.: VOC emissions from Norway spruce (Picea abies L. Karst) twigs in the field - results of a dynamic enclosure study, Atmos. Environ., 40, S128-S137, 2006.

Guenther, A.: Seasonal and spatial variations in natural volatile organic compound emissions, Ecol. Appl., 7, 34-45, 1997.

Guenther, A., Geron, C., Pierce, T., Lamb, B., Harley, P., and Fall, R.: Natural emissions of non-methane volatile organic compounds, carbon monoxide, and oxides of nitrogen from North America, Atmos. Environ., 34, 2205-2230, 2000.

Guenther, A., Hewitt, C. N., Erickson, D., Fall, R., Geron, C., Graedel, T., Harley, P., Klinger, L., Lerdau, M., McKay, W. A., Pierce, T., Scholes, B., Steinbrecher, R., Tallamraju, R., Taylor, J., and Zimmerman, P.: A global model of natural volatile organic compound emissions, J. Geophys. Res., 100, 8873-8892, 1995.

Guenther, A. and Hills, A.: Eddy covariance measurement of isoprene fluxes, J. Geophys. Res.-Atmos., 103(D11), 13145-13152, 1998.

Guenther, A., Karl, T., Harley, P., Wiedinmyer, C., Palmer, P. I., and Geron, C.: Estimates of global terrestrial isoprene emissions using MEGAN (Model of Emissions of Gases and Aerosols from Nature), Atmos. Chem. Phys., 6, 3181-3210, 2006, http://www.atmos-chem-phys.net/6/3181/2006/.

Guenther, A. B., Monson, R. K., and Fall, R.: Isoprene and monoterpene emission rate variability: observations with Eucalyptus and emission rate algorithm development, J. Geophys. Res., 96, 10799-10808, 1991.

Guenther, A., Zimmerman, P., Harley, P., Monson, R., and Fall, R.: Isoprene and monoterpene emission rate variability: model evaluations and sensitivity analysis, J. Geophys. Res., 98, 1260912617, 1993.

Guenther, A., Zimmerman, P., Klinger, L., Greenberg, J., Ennis, C., Davis, K., Pollock, M., Westberg, H., Allwine, G., and Geron, C.: Estimates of regional natural volatile organic compound fluxes from enclosure and ambient measurements, J. Geophys. Res., 101, 1345-1359, 1996.

Guenther, A., Zimmerman, P. R., and Wildermuth, M.: Natural volatile organic compound emission rates for U.S. woodland landscapes, Atmos. Environ., 28, 1197-1210, 1994.

Gracia, C., Tello, E., Sabate, S., and Bellot, J.: GOTILWA: An integrated model of water dynamics and forest growth, in: Ecology of Mediterranean Evergreen Oak Forests, edited by: Roda, F., Gracia, C., Retana, J., Bellot, J., Springer-Verlag, Heidelberg, 163-180, 1999.

Grote, R.: Sensitivity of volatile monoterpene emission to changes in canopy structure - a model based exercise with a processbased emission model, New Phytol., 173, 550-561, 2006.

Grote, R. and Niinemets, Ü.: Modeling volatile isoprenoid emissions - a story with split ends, Plant Biology, 10, 8-28, 2008.

Hakola, H., Laurila, T., Lindfors, V., Hellen, H., Gaman, A., and Rinne, J.: Variation of the VOC emission rates of birch species during the growing season, Boreal Environ. Res., 6, 237-249, 2001.

Hakola, H., Rinne, J., and Laurila, T.: The hydrocarbon emission rates of tea-leafed willow (Salix phylicifolia), silver birch (Betula pendula) and European aspen (Populus tremula), Atmos. Environ., 32, 1825-1833, 1998.

Hakola, H., Rinne, J., and Laurila, T.: The VOC emission rates of boreal deciduous trees, in: Biogenic VOC emissions and photochemistry in the boreal regions of Europe - Biphorep, edited by: Laurila, T. and Lindfors, V., European Commission, Brussels, 21-28, 1999.

Hakola, H., Tarviainen, V., Laurila, T., Hiltunen, V., Hellén, H., and Keronen, P.: Seasonal variation of VOC concentrations above a boreal coniferous forest, Atmos. Environ., 37, 1623-1634, 2003.

Hansen, U., and Seufert, G.: The terpenoid emission pattern of Quercus coccifera L. coincides with the emission pattern found with Quercus ilex L., in: The proceedings of EUROTRAC symposium 1996, edited by: Borrell, P. M., Borrell, P., Cvitas, T., Kelly, K., and Seile, W., Computational Mechanics Publications, Southampton, 235-239, 1996.

Hanson, D. T. and Sharkey, T. D.: Rate of acclimation of the capacity for isoprene emission in response to light and temperature, Plant Cell Environ., 24, 937-946, 2001.

Hansen, U., van Eijk, J., Bertin, N., Staudt, M., Kotzias, D., Seufert, G., Fugit, J. L., Torres, L., Cecinato, A., Brancaleoni, E., Ciccioli, P., and Bomboi, T.: Biogenic emissions and $\mathrm{CO}_{2}$ gas exchange investigated on four Mediterranean shrubs, Atmos. Environ., 31, 157-166, 1997.

Harley, P., Deem, G., Flint, S., and Caldwell, M.: Effects of growth under elevated UV-B on photosynthesis and isoprene emission in Quercus gambelii and Mucuna pruriens, Glob. Change Biol., 2, 149-154, 1996.

Harley, P., Vasconcellos, P., Vierling, L., Pinheiro, C., Greenberg, J., Guenther, A., Klinger, L., De Almeida, S. S., Neill, D., Baker, T., Phillips, O., and Malhi, Y.: Variation in potential for isoprene emissions among Neotropical forest sites, Glob. Change Biol., 10, 630-650, 2004.

Harrison, D., Hunter, M. C., Lewis, A. C., Seakins, P. W., Nunes, T. V., and Pio, C. A.: Isoprene and monoterpene emission from the coniferous species Abies borisii-regis - implications for regional air chemistry in Greece, Atmos. Environ., 35, 4687-4698, 2001.

Hills, A. J. and Zimmerman, P. R.: Isoprene measurement by ozone-induced chemiluminescence, Anal. Chem., 62, 10551060, 1990.

He, C., Murray, F., and Lyons, T.: Monoterpene and isoprene emissions from 15 Eucalyptus species in Australia, Atmos. Environ., 34, 645-655, 2000.

Helmig, D., Ortega, J., Guenther, A., Herrick, J. D., and Geron, C.: Sesquiterpene emissions from loblolly pine and their potential contribution to biogenic aerosol formation in the Southeastern US, Atmos. Environ., 40, 4150-4157, 2006. 
Hewitt, C. N. and Street, R. A.: A qualitative assessment of the emission of non-methane hydrocarbon compounds from the biosphere to the atmosphere in the UK: present knowledge and uncertainties, Atmos. Environ., 26A, 3069-3077, 1992.

Isebrands, J. G., Guenther, A. B., Harley, P., Helmig, D., Klinger, L., Vierling, L., Zimmerman, P., and Geron, C.: Volatile organic compound emission rates from mixed deciduous and coniferous forests in Northern Wisconsin, USA, Atmos. Environ., 33, 25272536, 1999.

Isidorov, V. A.: Non-methane hydrocarbons in the atmosphere of boreal forests: composition, emission rates, estimation of regional emission and photocatalytic transformation, Ecol. Bull., 42, 71-76, 1992.

Isidorov, V. A., Zenkevich, I. G., and Ioffe, B. V.: Volatile organic compounds in the atmosphere of forests, Atmos. Environ., 19, $1-8,1985$.

Janson, R. W.: Monoterpene emissions from Scots pine and Norwegian spruce, J. Geophys. Res., 98, 2839-2850, 1993.

Kanakidou, M., Seinfeld, J. H., Pandis, S. N., Barnes, I., Dentener, F. J., Facchini, M. C., Van Dingenen, R., Ervens, B., Nenes, A., Nielsen, C. J., Swietlicki, E., Putaud, J. P., Balkanski, Y., Fuzzi, S., Horth, J., Moortgat, G. K., Winterhalter, R., Myhre, C. E. L., Tsigaridis, K., Vignati, E., Stephanou, E. G., and Wilson, J.: Organic aerosol and global climate modelling: a review, Atmos. Chem. Phys., 5, 1053-1123, 2005,

http://www.atmos-chem-phys.net/5/1053/2005/.

Kaplan, J. O., Folberth, G., and Hauglustaine, D. A.: Role of methane and biogenic volatile organic compound sources in late glacial and Holocene fluctuations of atmospheric methane concentrations, Global Biogeochem. Cy., 20, GB2016, doi:10.1929/2005GB002590, 2006.

Karl, T. G., Spirig, C., Rinne, J., Stroud, C., Prevost, P., Greenberg, J., Fall, R., and Guenther, A.: Virtual disjunct eddy covariance measurements of organic compound fluxes from a subalpine forest using proton transfer reaction mass spectrometry, Atmos. Chem. Phys., 2, 279-291, 2002,

http://www.atmos-chem-phys.net/2/279/2002/.

Karlik, J. F. and Winer, A. M.: Measured isoprene emission rates of plants in California landscapes: comparison to estimates from taxonomic relationships, Atmos. Environ., 35, 1123-1131, 2001.

Keenan, T., Sabate, S., and Gracia, C.: Forest ecophysiological models and carbon sequestration, in: Managing Forest Ecosystems - The Challenge of Climate Change, edited by: Bravo, F., LeMay, V., Jandl, R., Gadow, K. v., Springer, Berlin, ISBN:9781-4020-8342-6, 83-102, 2008.

Keenan, T., García, R., Friend, A. D., Zaehle, S., Gracia, C., and Sabate, S.: Improved understanding of drought controls on seasonal variation in Mediterranean forest canopy $\mathrm{CO}_{2}$ and water fluxes through combined in situ measurements and ecosystem modelling, Biogeosciences Discuss., 6, 2285-2329, 2009, http://www.biogeosciences-discuss.net/6/2285/2009/.

Kempf, K., Allwine, E., Westberg, H., Claiborn, C., and Lamb, B.: Hydrocarbon emissions from spruce species using environmental chamber and branch enclosure methods, Atmos. Environ., 30, 1381-1389, 1996.

Kesselmeier, J., Bode, K., Hofmann, U., Müller, H., Schäfer, L., Wolf, A., Ciccioli, P., Brancaleoni, E., Cecinato, A., Frattoni, M., Foster, P., Ferrari, C., Jacob, V., Fugit, J. L., Dutaur, L., Simon, V., and Torres, L.: Emission of short chained organic acids, alde- hydes and monoterpenes from Quercus ilex L. and Pinus pinea L. in relation to physiological activities, carbon budget and emission algorithms, Atmos. Environ., 31, 119-133, 1997.

Kesselmeier, J., Bode, K., Schäfer, L., Schebeske, G., Wolf, A., Brancaleoni, E., Cecinato, A., Ciccioli, P., Frattoni, M., Dutaur, L., Fugit, J. L., Simon, V., and Torres, L.: Simultaneous field measurements of terpene and isoprene emissions from two dominant Mediterranean oak species in relation to a north American species, Atmos. Environ., 32, 1947-1953, 1998.

Kesselmeier, J. and Staudt, M.: Biogenic volatile organic compounds (VOC): an overview on emission, physiology and ecology, J. Atmos. Chem., 33, 23-88, 1999.

Klinger, L. F., Li, Q.-J., Guenther, A. B., Greenberg, J. P., Baker, B., and Bai, J.-H.: Assessment of volatile organic compound emissions from ecosystems of China, J. Geophys. Res.-Atmos., 107, 4603, doi:10.1029/2001JD001076. , 2002.

Knöppel, H., Versino, B., Peil, A., Schauenburg, H., and Vissers, H.: Quantitative determination of terpenes emitted by conifers, in: Proceedings of the 2nd European symposium on physicochemical behaviour of atmospheric pollutants, Varese, Italy, September 29 October 2001, Joint Research Center, Ispra, 8998, 1981.

Komenda, M. and Koppmann, R.: Monoterpene emissions from Scots pine (Pinus sylvestris): field studies of emission rate variabilities, J. Geophys. Res., 107, 4161, doi:10.1029/2001JD000691, 2002.

König, G., Brunda, M., Puxbaum, H., Hewitt, C. N., Duckham, S. C., and Rudolph, J.: Relative contribution of oxygenated hydrocarbons to the total biogenic VOC emissions of selected MidEuropean agricultural and natural plant species, Atmos. Environ., 29, 861-874, 1995.

Kuhn, U., Rottenberger, S., Biesenthal, T., Wolf, A., Schebeske, G., Ciccioli, P., and Kesselmeier, J.: Strong correlation between isoprene emission and gross photosynthetic capacity during leaf phenology of the tropical tree species Hymenaea courbaril with fundamental changes in volatile organic compounds emission composition during early leaf development, Plant Cell Environ., 27, 1067-1485, 2004.

Kulmala, M., Suni, T., Lehtinen, K. E. J., Dal Maso, M., Boy, M., Reissell, A., Rannik, U., Aalto, P., Keronen, P., Hakola, H., Bäck, J., Hoffmann, T., Vesala, T., and Hari, P.: A new feedback mechanism linking forests, aerosols, and climate, Atmos. Chem. Phys., 4, 557-562, 2004,

http://www.atmos-chem-phys.net/4/557/2004/.

Leinonen, I.: Dependence of dormancy release on temperature in different origins of Pinus sylvestris and Betula pendula seedlings, Scand. J. For. Res. 11, 122-128, 1996.

Lamb, B., Gay, D., Westberg, H., and Pierce, T.: A biogenic hydrocarbon emission inventory for the U.S. using a simple forest canopy model, Part A, Atmos. Environ., 27, 1673-1690, 1993.

Lamb, B., Westberg, H., Quarles, T., and Flyckt, D.: Natural hydrocarbon emission rate measurements from vegetation in Pennsylvania and Washington, Report PB84-124981, US. Environmental Protection Agency, Nat. Tech. Inf. Serv., Springfield, Virginia, USA, 1983.

Lavoir, A. V., Staudt, M., Schnitzler, J. P., Landais, D., Massol, F., Rocheteau, A., Rodriguez, R., Zimmer, I., and Rambal, S.: Drought reduced monoterpene emissions from Quercus ilex trees: results from a throughfall displacement experiment within 
a forest ecosystem, Biogeosciences Discuss., 6, 863-893, 2009, http://www.biogeosciences-discuss.net/6/863/2009/.

Lathière, J., Hauglustaine, D. A., Friend, A. D., De NobletDucoudré, N., Viovy, N., and Folberth, G. A.: Impact of climate variability and land use changes on global biogenic volatile organic compound emissions, Atmos. Chem. Phys., 6, 2129-2146, 2006, http://www.atmos-chem-phys.net/6/2129/2006/.

Lehning, A., Zimmer, I., Steinbrecher, R., Brüggemann, N., and Schnitzler, J. P.: Isoprene synthase activity and its relation to isoprene emission in Quercus robur L. leaves, Plant Cell Environ., 22, 495-504, 1999.

Lenz, R., Selige, T., and Seufert, G.: Scaling up the biogenic emissions from test sites at Castelporziano, Atmos. Environ., 31, 239250, 1997.

Lenz, R., Köble, R., and Seufert, G.: Species-based mapping of biogenic emissions in Europe - case study Italy, in: A changing atmosphere: 8th European symposium on the physico-chemical behaviour of atmospheric pollutants, 17-20 September 2001, Lingotto Conference Centre, Torino (Italy), edited by: Hjorth, J., Raes, F., and Angeletti, G., Joint Research Center, Ispra, 2001.

Le Quere, C.: The unknown and the uncertain in earth system modeling, EOS Transactions, American Geophysical Union, 87, 496-496, 2006.

Leuning, R., Kelliher, F. M., de Pury, D. G. G., and Schulze, E.D.: Leaf nitrogen, photosynthesis, conductance and transpiration: scaling from leaves to canopies, Plant Cell Environ., 18, 1183-1200, 1995.

Levis, S., Foley, J. A., and Pollard, D.: Potential high-latitude vegetation feedbacks on $\mathrm{CO}_{2}$-induced climate change, Geophys. Res. Lett., 26, 747-750, 1999.

Lindskog, A. and Potter, A.: Terpene emission and ozone stress, Chemosphere, 30, 1171-1181, 1995.

Litvak, M. E., Madronich, S., and Monson, R. K.: Herbivoreinduced monoterpene emissions from coniferous forests: potential impact on local tropospheric chemistry, Ecol. Appl., 9, 11471159, 1999.

Llusià, J. and Peñuelas, J.: Seasonal patterns of terpene content and emission from seven Mediterranean woody species in field conditions, Am. J. Bot., 87, 133-140, 2000.

Llusia, J. and Peñuelas, J.: Changes in terpene content and emission in potted Mediterranean woody plants under severe drought, Can. J. Botany, 76, 1366-1373, 1998.

Loreto, F., Mannozzi, M., Maris, C., Nascetti, P., Ferranti, F., and Pasqualini, S.: Ozone quenching properties of isoprene and its antioxidant role in leaves, Plant Physiol., 126, 993-1000, 2001.

Loreto, F. and Velikova, V.: Isoprene production by leaves protects the photosynthetic apparatus against ozone damage, quenches ozone products, and reduces lipid peroxidation of cellular membranes, Plant Physiol., 127, 1781-1787, 2001.

Loreto, F. and Sharkey, T. D.: A gas-exchange study of photosynthesis and isoprene emission in Quercus rubra L., Planta, 182, 523-531, 1990.

Loreto, F. and Sharkey, T. D.: On the relationship between isoprene emission and photosynthetic metabolites under different environmental conditions, Planta, 189, 420-424, 1993.

Luchetta, L.: Les composés organiques volatils biogéniques et anthropiques dans la basse atmosphère: caractérisation et sources. Institut National Polytechnique Toulouse, France, Toulouse, 1999.
McGuire, A. D., Sitch, S., Clein, J. S., Dargaville, R., Esser, G., Foley, J., Heimann, M., Joos, F., Kaplan, J., Kicklighter, D. W., Meier, R. A., Melillo, J. M., Moore, B., Prentice, I. C., Ramankutty, N., Reichenau, T., Schloss, A., Tian, H., Williams, L. J., and Wittenberg, U.: Carbon balance of the terrestrial biosphere in the twentieth century: analyses of $\mathrm{CO}_{2}$, climate and land use effects with four process-based ecosystem models, Global Biogeochem. Cy., 15, 183-206, 2001.

Magel, E., Mayrhofer, S., Mller, A., Zimmer, I., Hampp, R. and Schnitzler, J. P.: Photosynthesis and substrate supply for isoprene biosynthesis in poplar leaves, Atmos. Environ., 40, 138$151,2006$.

Martin, M. J., Stirling, C. M., Humphries, S. W., and Long, S. P.: A process-based model to predict the effects of climatic change on leaf isoprene emission rates, Ecol. Model., 131, 161-174, 2000.

Miller, B., Madilao, L. L., Ralph, S., and Bohlmann, J.: Insect induced conifer defense. White pine weevil and methyl jasmonate induce traumatic resinosis, de novo formed volatile emissions, and accumulation of terpenoid synthase and putative octadecanoid pathway transcripts in Sitka spruce, Plant Physiol., 137, 369-382, 2005.

Monson, R. K. and Fall, R.: Isoprene emission from aspen leaves. The influence of environment and relation to photosynthesis and photorespiration, Plant Physiol., 90, 267-274, 1989.

Monson, R. K., Harley, P. C., Litvak, M. E., Wildermuth, M., Guenther, A. B., Zimmerman, P. R., and Fall, R.: Environmental and developmental controls over the seasonal pattern of isoprene emission from aspen leaves, Oecologia, 99, 260-270, 1994.

Monson, R. K. and Holland, E.: Biospheric trace gas fluxes and their control over tropospheric chemistry, Annu. Rev. Ecol. Syst., 32, 547-576, 2001.

Monson, R. K., Trahan, N., Rosenstiel, T. N., Veres, P., Moore, D., Wilkinson, M., Norby, R. I., Volder, A., Tjoelker, M. G., Briske, D. D., Karnosky, D. F., and Fall, R.: Isoprene emission from terrestrial ecosystems in response to global change: minding the gap between models and observations, Philos. T. R. Soc. A., 365 , 1677-1695, 2008.

Monson, R. K., Jaeger, C. H., Adams, W. W. I., Driggers, E. M., Silver, G. M., and Fall, R.: Relationship among isoprene emission rate, photosynthesis, and isoprene synthase activity as influenced by temperature, Plant Physiol., 98, 1175-1180, 1992.

Moukhtar, S., Bessagnet, B., Rouil, L., and Simon, V.: Monoterpene emissions from beech (Fagus sylvatica) in a French forest and impact on secondary pollutants formation at regional scale, Atmos. Environ., 39, 3535-3547, 2005.

Naik, V., Delire, C., and Wuebbles, D. J.: Sensitivity of global biogenic isoprenoid emissions to climate variability and atmospheric $\mathrm{CO}_{2}$, J. Geophys. Res.-Atmos., 109, D06301, doi:06310.01029/02003JD004236, 2004.

New, M., Hulme, M., and Jones, P. D.: Representing twentieth century space-time climate variability. Part 1: Development of a 1961-1990 mean monthly terrestrial climatology, J. Climate, 12, 829-856, 1999.

Niinemets, Ü.: Research review. Components of leaf dry mass per area - thickness and density - alter leaf photosynthetic capacity in reverse directions in woody plants, New Phytol., 144, 35-47, 1999.

Niinemets, Ü.: Costs of production and physiology of emission of 
volatile leaf isoprenoids, in: Advances in Plant Physiol, edited by: Hemantaranjan, A., Scientific Publishers, Jodhpur, 241-278, 2004.

Niinemets, Ü., Hauff, K., Bertin, N., Tenhunen, J. D., Steinbrecher, R., and Seufert, G.: Monoterpene emissions in relation to foliar photosynthetic and structural variables in Mediterranean evergreen Quercus species, New Phytol., 153, 243-256, 2002a.

Niinemets, $\ddot{U}$. and Reichstein, M.: Controls on the emission of plant volatiles through stomata: sensitivity or insensitivity of the emission rates to stomatal closure explained, J. Geophys. Res.Atmos., 108, 4208, doi:4210.1029/2002JD002620, 2003.

Niinemets, Ü., Seufert, G., Steinbrecher, R., and Tenhunen, J. D.: A model coupling foliar monoterpene emissions to leaf photosynthetic characteristics in Mediterranean evergreen Quercus species, New Phytol., 153, 257-276, 2002 b.

Niinemets, Ü., Tenhunen, J. D., Harley, P. C., and Steinbrecher, R.: A model of isoprene emission based on energetic requirements for isoprene synthesis and leaf photosynthetic properties for Liquidambar and Quercus, Plant Cell Environ., 22, 13191335, 1999.

Noe, S. M., Peñuelas, J., and Niinemets, Ü.: Monoterpene emissions from ornamental trees in urban areas: a case study of Barcelona, Spain, Plant Biology, 10, 163-169, 2008.

Ormeño, E., Fernandez, C., Bousquet-Mélou, A., Greff, S., Morin, E., Robles, C., Vila, B., and Bonin, G.: Monoterpene and sesquiterpene emissions of three Mediterranean species through calcareous and siliceous soils in natural conditions, Atmos. Environ., 41, 629-639, 2007.

Otter, L. B., Guenther, A., and Greenberg, J.: Seasonal and spatial variations in biogenic hydrocarbon emissions from southern African savannas and woodlands, Atmos. Environ., 36, 42654275, 2002.

Otter, L., Guenther, A., Wiedinmyer, C., Fleming, G., Harley, P., and Greenberg, J.: Spatial and temporal variations in biogenic volatile organic compound emissions for Africa south of the equator, J. Geophys. Res.-Atmos., 108, 8505, doi:10.1029/2002JD002609, 2003.

Owen, S.: Emissions of isoprene and monoterpenes from native Mediterranean vegetation. $\mathrm{PhD}$ Thesis, Lancaster University, Lancaster, 1998.

Owen, S., Boissard, C., Street, R. A., Duckham, S. C., Csiky, O., and Hewitt, C. N.: Screening of 18 Mediterranean plant species for volatile organic compound emissions, Atmos. Environ., 31, 101-117, 1997.

Owen, S. M., Boissard, C., Hagenlochera, B., and Hewitt, C. N.: Field studies of isoprene emissions from vegetation in the Northwest Mediterranean region, J. Geophys. Res.-Atmos., 103, 25499-25511, 1998.

Owen, S. M., Boissard, C., and Hewitt, C. N.: Volatile organic compounds (VOCs) emitted from 40 Mediterranean plant species: VOC speciation and extrapolation to habitat scale, Atmos. Environ., 35, 5393-5409, 2001.

Owen, S. M., Harley, P., Guenther, A., and Hewitt, C. N.: Light dependency of VOC emissions from selected Mediterranean plant species, Atmos. Environ., 36, 3147-3159, 2002.

Owen, S. M. and Hewitt, C. N.: Extrapolating branch enclosure measurements to estimates of regional scale biogenic VOC fluxes in the northwestern Mediterranean basin, J. Geophys. Res.Atmos., 105, 11573-11583, 2000.
Owen, S. M., MacKenzie, A. R., Stewart, H., Donovan, R., and Hewitt, C. N.: Biogenic volatile organic compound (VOC) emission estimates from an urban tree canopy, Ecol. Appl., 13, 927-938, 2003.

Owen, S. and Peñuelas, J.: Opportunistic emissions of volatile isoprenoids, Trends Plant Sci., 10, 420-427, 2005.

Parra, R., Gassó, S., and Baldasano, J. M.: Estimating the biogenic emissions of non-methane volatile organic compounds from the North Western Mediterranean vegetation of Catalonia, Spain, Sci. Total Environ., 329, 241-259, 2004.

Pegoraro, E., Rey, A., Bobich, E. G., Barron-Gafford, G. A., Grieve, K. A., Mahli, Y., and Murthy, R.: Effect of elevated $\mathrm{CO}_{2}$ concentration and vapour pressure deficit on isoprene emission from leaves of Populus deltoides during drought, Funct. Plant Biol., 31, 1137-1147, 2004a.

Pegoraro, E., Rey, A., Greenberg, J., Harley, P., Grace, J., Mahli, Y., and Guenther, A.: Effect of drought on isoprene emission rates from leaves of Quercus virginiana, Mill. Atmos. Environ., 38, 6149-6156, 2004b.

Pegoraro, E., Potosnak, M. J., Monson, R. K., Rey, A., BarronGafford, G., Osmond, C. B.: The effect of elevated $\mathrm{CO}_{2}$, soil and atmospheric water deficit and seasonal phenology on leaf and ecosystem isoprene emission. Funct. Plant Biol., 34, 77484, 2007.

Peñuelas, J. and Llusià, J.: The complexity of factors driving volatile organic compound emissions by plants, Biol. Plantarum, 44, 481-487, 2001.

Peñuelas, J. and Llusià, J.: BVOCs: Plant defense against climate warming? Trends Plant Sci., 8, 105-109, 2003.

Peñuelas, J. and Llusià, J.: Plant VOC emissions: Making use of the unavoidable, Trends Ecol. Evol., 8, 402-404, 2004.

Peñuelas, J., Llusià, J., Asensio, D., and Munné-Bosch, S.: Linking isoprene with plant thermotolerance, antioxidants and monoterpene emissions, Plant Cell Environ., 28, 278-286, 2005.

Petron, G., Harley, P., Greenberg, J., and Guenther, A.: Seasonal temperature variations influence isoprene emissions, Geophys. Res. Lett., 28, 1707-1710, 2001.

Pelkonen, P. and Hari, P.: The dependence of the springtime recovery of $\mathrm{CO}_{2}$ uptake in Scots pine on temperature and internal factors, Flora, 169, 398-404, 1980.

Pio, C. A., Nuñes, T. V., and Brito, S.: Volatile hydrocarbon emissions from common and native species of vegetation in Portugal, in: Proceedings of the joint Workshop of CEC/BIATEX of EUROTRAC. General Assessment of Biogenic Emissions and Deposition of Nitrogen Compounds, Sulfur compounds and oxidants in Europe, edited by: Slanina, J., Angeletti, G., and Beilke, S., EC, Directorate-General for Science, Research and Development, Aveiro, Portugal, 291-298, 1993.

Pio, C. A., Nunes, T. V., and Valente, A. R.: Biogenic hydrocarbon emissions from vegetation in a southern European environment, in: The proceedings of EUROTRAC symposium 1996, edited by: Borrell, P. M., Borrell, P., Cvitas, T., Kelly, K., and Seile, W., Computational Mechanics Publications, Southampton, 3543, 1996.

Pio, C. A., Silva, P. A., Cerqueira, M. A., and Nuñes, T. V.: Diurnal and seasonal emissions of volatile organic compounds from cork oak (Quercus suber) trees, Atmos. Environ., 39, 1817-1827, 2005.

Poisson, N., Kanakidou, M., and Crutzen, P. J.: Impact of 
non-methane hydrocarbons on tropospheric chemistry and the oxidizing power of the global troposphere: 3-dimensional modeling results, J. Atmos. Chem., 36, 157-230, 2000.

Possell, M., Heath, J., Hewitt, C. N., Ayres, E., and Kerstiens, G.: Interactive effects of elevated $\mathrm{CO}_{2}$ and soil fertility on isoprene emissions from Quercus robur, Glob. Change Biol., 10, 18351843, 2004.

Pressley, S., Lamb, B., Westberg, H., Flaherty, J., Chen, J., and Vogel, C.: Long-term isoprene flux measurements above a northern hardwood forest, J. Geophys. Res., 110, D07301, doi:10.1029/2004JD005523, 2005.

Pressley, S., Lamb, B., Westberg, H., and Vogel, C.: Relationships among canopy scale energy fluxes and isoprene flux derived from long-term, seasonal eddy covariance measurements over a hardwood forest, Agr. Forest Meteorol., 136, 188-202, 2006

Projections, U.E.T.F.o.E.I.a. Group 11: Other sources and sinks, in EMEP/CORINAIR emission inventory guidebook - 2007, EEA (European Environment Agency), Copenhagen, Denmark, 2007.

Puxbaum, H.: Biogenic emissions of alcohols, esters, ether and other aldehydes, in: Biogenic volatile organic compounds in the atmosphere, edited by: Helas, G., Slanina, S., and Steinbecher, R., SPB Academic Publishing, Amsterdam, 79-99, 1997.

Rabong, R. and Steinbrecher, R.: VOC emissions from selected oak trees and from pseudo-steppe vegetation types, VOCs and peroxides above an oak/pine forest at Castelporziano, Rome, EUR Report 16293 EN, Office for official publications of the European Communities, Luxembourg, 151-172, 1995.

Rapparini, F., Baraldi, R., Miglietta, F., and Loreto, F.: Isoprenoid emission in trees of Quercus pubescens and Quercus ilex with lifetime exposure to naturally high $\mathrm{CO}_{2}$ environment, Plant Cell Environ., 27, 381-391, 2004.

Rasmussen, R. A.: Isoprene plant species list. Special report of Air Pollution Research Section. Washington State University, Pullman, 1978.

Rinne, H. J. I., Delany, A. C., Greenberg, J. P., and Guenther, A. B.: A true eddy accumulation system for trace gas fluxes using disjunct eddy sampling method, J. Geophys. Res.-Atmos., 105, 24791-24798, 2000.

Roelofs, G. J. and Lelieveld, J.: Tropospheric ozone simulation with a chemistry-general circulation model: influence of higher hydrocarbon chemistry, J. Geophys. Res., 105(22), 697-22712, 2000.

Rosenstiel, T. N., Fisher, A. J., Fall, R., and Monson, R. K.: Differential accumulation of dimethylallyl diphosphate in leaves and needles of isoprene- and methylbutenol-emitting and nonemitting species. Plant Physiol., 129, 1276-1284, 2002.

Sabillón, D. and Cremades, L. V.: Diurnal and seasonal variation of monoterpene emission rates for typical Mediterranean species (Pinus pinea and Quercus ilex) from field measurements - relationship with temperature and PAR, Atmos. Environ., 35, 44194431, 2001.

Schaab, G., Steinbrecher, R., and Lacaze, B.: Influence of seasonality, canopy light extinction, and terrain on potential isoprenoid emission from a Mediterranean-type ecosystem in France, J. Geophys. Res.-Atmos., 108, 1-14, 2003.

Schroter, D., Cramer, W., Leemans, R., Prentice, C., Araujo, M., Arnell, N., Bondeau, A., Bugmann, H., Carter, T., Gracia, C., de la Vega-Leinert, A., Erhard, M., Ewert, F., Glendining, M., House, J., Kankaanpaa, S., Klein, R., Lavorel, S., Lindner, M.,
Metzger, M., Meyer, J., Mitchell, T., Reginster, I., Rounsevell, M., Sabaté, S., Sitch, S., Smith, B., Smith, J., Smith, P., Sykes, M., Thonicke, K., Thuiller, W., Tuck, G., Zaehle, S., and Zierl, B.: Ecosystem service supply and vulnerability to Global Change in Europe, Science, 310, 1333-1337, 2005.

Schuh, G., Heiden, A. C., Hoffmann, T., Kahl, J., Rockel, P., Rudolph, J., and Wildt, J.: Emissions of volatile organic compounds from sunflower and beech: dependence on temperature and light intensity, J. Atmos. Chem., 27, 291-318, 1997.

Schürmann, W.: Emission von Monoterpenen aus Nadeln von Picea abies (L.) Karst. sowie deren Verhalten in der Atmosphäre, Dr. Rer. Nat. Thesis, Fakultät für Chemie, Biologie und Geowissenchaften der Technischen Universität München, Munich, Germany, 1993.

Seufert, G., Bartzis, J., Bombol, T., Ciccioli, P., Cieslik, S., Dlugi, R., Foster, P., Hewitt, C. N., Kesselmeier, J., Kotzias, D., Lenz, R., Manes, F., Perez Pastor, P., Steinbrecher, R., Torres, L., Valentini, R., and Versino, B.: An overview of the Castelporziano experiments, Atmos. Environ., 31, 5-17, 1997.

Shao, M., Czapiewski, K. V., Heiden, A. C., Kobel, K., Komenda, M., Koppmann, R., and Wildt, J.: Volatile organic compound emissions from Scots pine: mechanisms and description by algorithms, J. Geophys. Res., 106, 20483-20491, 2001.

Sharkey, T. D.: Effects of moderate heat stress on photosynthesis: importance of thylakoid reactions, Rubisco deactivation, reactive oxygen species, and thermotolerance provided by isoprene, Plant Cell Environ., 28, 269-277, 2005.

Sharkey, T. D., and Singsaas, E. L.: Why plants emit isoprene, Nature, 374, p. 769, 1995.

Sharkey, T. D. and Yeh, S.: Isoprene emission from plants, Annu. Rev. Plant Phys., 52, 407-436, 2001.

Simon, V., Clement, B., Riba, M. L., and Torres, L.: The Landes experiment: monoterpenes emitted from maritime pine, J. Geophys. Res., 99, 16501-16510, 1994.

Simon, V., Dumergues, L., Ponche, J. L, Torres, L.: The biogenic volatile organic compounds emission inventory in France: Application to plant ecosystems in the Berre-Marseilles area (France), Sci. Total Environ., 372, 164-182, 2006.

Simpson, D., Guenther, A., Hewitt, C. N., and Steinbrecher, R.: Biogenic emissions in Europe. 1. Estimates and uncertainties, J. Geophys. Res., 100, 22875-22890, 1995.

Simpson, D., Winiwarter, W., Börjesson, G., Cinderby, S., Ferreiro, A., Guenther, A., Hewitt, C. N., Janson, R., Khalil, M. A. K., Owen, S., Pierce, T. E., Puxbaum, H., Shearer, M., Skiba, U., Steinbrecher, R., Tarrasón, L., and Öquist, M. G.: Inventorying emissions from nature in Europe, J. Geophys. Res.-Atmos., 104, 8113-8152, 1999.

Smith, B., Prentice, I. C., and Sykes, M. T.: Representation of vegetation dynamics in the modelling of terrestrial ecosystems: comparing two contrasting approaches within European climate space, Global Ecol. Biogeogr., 10, 621-637, 2001.

Solmon, F., Sarrat, C., Serça, D., Tulet, P., and Rosset, R.: Isoprene and monoterpenes biogenic emissions in France: modeling and impact during a regional pollution episode, Atmos. Environ., 38, 3853-3865, 2004.

Spirig, C., Neftel, A., Ammann, C., Dommen, J., Grabmer, W., Thielmann, A., Schaub, A., Beauchamp, J., Wisthaler, A., and Hansel, A.: Eddy covariance flux measurements of biogenic VOCs during ECHO 2003 using proton transfer reaction mass 
spectrometry, Atmos. Chem. Phys., 5, 465-481, 2005, http://www.atmos-chem-phys.net/5/465/2005/.

Staudt, M.: Untersuchungen der Monoterpen-Abgabe an europäischen Nadelbaumarten in Abhängigkeit von Umweltfaktoren. PhD Thesis, Universität Hohenheim, Documenta Naturae 111, ISSN 0723-8428, Verlag Documenta naturae, München, Stuttgart, 1997.

Staudt, M., Bertin, N., Hansen, U., Seufert, G., Ciccioli, P., Foster, P., Frenzel, B., and Fugit, J. L.: Seasonal and diurnal patterns of monoterpene emissions from Pinus pinea $(L$.) under field conditions, Atmos. Environ., 31, 145-156, 1997.

Staudt, M., Mir, C., Joffre, R., Rambal, S., Bonin, A., Landais, D., and Lumaret, R.: Isoprenoid emissions of Quercus spp. (Q. suber and $Q$. ilex) in mixed stands contrasting in interspecific genetic introgression, New Phytol., 163, 573-584, 2004.

Staudt, M. and Bertin, N.: Light and temperature dependence of the emission of cyclic and acyclic monoterpenes from holm oak (Quercus ilex L.) leaves, Plant Cell Environ., 21, 385-395, 1998.

Steinbrecher, R.: Emissions of selected European ecosystems: the state of the art, in: The proceedings of EUROTRAC symposium '94, edited by: Borrell, P. M., Borrell, P., Cvitas, T., and Seiler, W., SPB Academic Publishers, The Hague, 448-454, 1994.

Steinbrecher, R.: Isoprene: production by plants and ecosystemlevel estimates, in: Biogenic volatile organic compounds in the atmosphere, edited by: Helas, G., Slanina, J., and Steinbrecher, R., SPB Academic Publishing bv, Amsterdam, 101-114, 1997.

Steinbrecher, R. and Hauff, K.: Isoprene and monoterpene emission from Mediterranean oaks, in: The proceedings of EUROTRAC symposium '96, edited by: Borrell, P. M., Borrell, P., Cvitas, T., Kelly, K., and Seiler, W., Computational Mechanics Publications, Southampton, 229-233, 1996.

Steinbrecher, R., Hauff, K., Rabong, R., and Steinbrecher, J.: Isoprenoid emission of oak species typical for the Mediterranean area: source strength and controlling variables, Atmos. Environ., 31, 79-88, 1997.

Steinbrecher, R., Schurmann, W., Schreiner, A.-M., and Ziegler, H.: Terpenoid emissions from common oak (Quercus robur L.) and Norway spruce (Picea abies (L.) Karst.), in: Proceedings of the joint Workshop of CEC/BIATEX of EUROTRAC. General Assessment of Biogenic Emissions and Deposition of Nitrogen Compounds, Sulfur compounds and oxidants in Europe, edited by: Slanina, J., Angeletti, G., and Beilke, S., EC, DirectorateGeneral for Science, Research and Development, Aveiro, Portugal, 251-257, 1993.

Street, R. A., Duckham, S. C., Boussard, C., and Hewitt, C. N.: Emissions of VOCs from stressed and unstressed vegetation, in: Biosphere-atmosphere exchange of pollutants and trace substances, edited by: Slanina, S., Springer Verlag, Berlin, 366-371, 1997a.

Street, R. A., Duckham, S. C., and Hewitt, C. N.: Laboratory and field studies of biogenic volatile organic compound emissions from Sitka spruce (Picea sitchensis Bong.) in the UK, J. Geophys. Res.-Atmos., 101, 22799-22806, 1996.

Street, R. A., Hewitt, C. N., and Mennicken, S.: Isoprene and monoterpene emissions from a Eucalyptus plantation in Portugal, J. Geophys. Res.-Atmos., 102, 15875-15887, 1997 b.

Street, R. A., Owen, S., Duckham, S. C., Boissard, C., and Hewitt, C. N.: Effect of habitat and age on variations in volatile organic compound (VOC) emissions from Quercus ilex and Pinus pinea,
Atmos. Environ., 31, 89-100, 1997c.

Szidat, S., Jenk, T. M., Synal, H. A., Kalberer, M., Wacker, L., Hajdas, I., Kasper-Giebl, A., and Baltensperger, U.: Contributions of fossil fuel, biomass-burning, and biogenic emissions to carbonaceous aerosols in Zurich as traced by C-14, J. Geophys. Res.-Atmos., 111, D07206, doi:10.1029/2005JD006590, 2006.

Tao, Z. and Jain, A. K.: Modeling of global biogenic emissions for key indirect greenhouse gases and their response to atmospheric $\mathrm{CO}_{2}$ increases and changes in land cover and climate, J. Geophys. Res.-Atmos., 110, D21309, doi:10.1029/22005JD005874, 2005.

Tarvainen, V., Hakola, H., Rinne, J., Hellen, H., and Haapanala, S.: Towards a comprehensive emission inventory of terpenoids from boreal ecosystems, Tellus B, 59, 526-534, 2007.

Tingey, D., Manning, M., Grothaus, L., and Burns, W.: Influence of light and temperature on monoterpene emission rates from slash pine, Plant Physiol., 65, 797-801, 1980.

Tollsten, L. and Müller, P. M.: Volatile organic compounds emitted from beech leaves, Phytochemistry, 43, 759-762, 1996.

Tunved, P., Hansson, H. C., Kerminen, V. M., Strom, J., Dal Maso, M., Lihavainen, H., Viisanen, Y., Aalto, P. P., Komppula, M., and Kulmala, M.: High natural aerosol loading over boreal forests, Science, 312, 261-263, 2006.

Valdes, P. J., Beerling, D. J., and Johnson, D. E.: The ice age methane budget, Geophys. Res. Lett., 32, L02704, doi:10.1029/02004GL021004, 2005.

van Poecke, R. M. and Dicke, M.: Indirect defence of plants against herbivores: using Arabidopsis thaliana as a model plant, Plant Biology, 6, 387-401, 2004.

Velikova, V. and Loreto, F.: On the relationship between isoprene emission and thermotolerance in Phragmites australis leaves exposed to high temperatures and during the recovery from a heat stress, Plant Cell Environ., 28, 318-327, 2005.

von Caemmerer, S. and Farquhar, G. D.: Some relationships between the biochemistry of photosynthesis and gas exchange of leaves, Planta, 153, 376-387, 1981.

Wang, Y. F., Owen, S., Li, Q. J., and Peñuelas, J.: Monoterpene emissions from rubber trees (Hevea brasiliensis) in a changing landscape and climate: chemical speciation and environmental control, Glob. Change Biol., 13, 2270-2282, 2007.

Wang, Y. P. and Leuning, R.: A two-leaf model for canopy conductance, photosynthesis and partitioning of available energy I: Model description and comparison with a multi-layered model, Agr. Forest Meteorol., 19, 89-111, 1998.

Wiberley, A. E., Linskey, A. R., Falbel, T. G., and Sharkey, T. D.: Development of the capacity for isoprene emission in $k u d z u$, Plant Cell Environ., 28, 898-905, 2005.

Wiedinmyer, C., Guenther, A., Harley, P., Hewitt, C., Geron, C., Artaxo, P., Steinbrecher, R., and Rasmussen, R.: Global organic emissions from vegetation, in: Emissions of atmospheric trace compounds, edited by: Granier, C., Kluwer Publishing C., Dordrecht, The Netherlands, 121-182, 2004.

Winer, A. M., Arey, J., Aschmann, S. M., Atkinson, R., Long, W. D., Morrison, L. C., and Olszyk, O. M.: Hydrocarbon emissions from vegetation found in California's Central Valley, Contract No. A732-155, prepared for the California Air Resources Board, Riverside, California, U.S.A., Statewide Air Pollution Research Center, Springfield, Virginia, USA, 1989.

Winer, A. M., Arey, J., Atkinson, R., Aschmann, S. M., Long, 
W. D., Morrison, C. L., and Olszyk, D. M.: Emission rates of organics from vegetation in California's Central Valley, Atmos. Environ., 26A, 2647-2659, 1992.

Winer, A. M., Fitz, D. R., and Miller, P. R.: Investigation of the role of natural hydrocarbons in photochemical smog formation in California, Contract No. AO-056-32, prepared for the California Air Resources Board. Riverside, California, USA, Statewide Air Pollution Research Center, Springfield, Virginia, USA, 1983.

Wright, I. J., Reich, P. B., Westoby, M., Ackerly, D. D., Baruch, Z., Bongers, F., Cavender-Bares, J., Chapin, T., Cornelissen, J. H. C., Diemer, M., Flexas, J., Garnier, E., Groom, P. K., Gulias, J., Hikosaka, K., Lamont, B. B., Lee, T., Lee, W., Lusk, C., Midgley, J. J., Navas, M. L., Niinemets, Ü., Oleksyn, J., Osada, N., Poorter, H., Poot, P., Prior, L., Pyankov, V. I., Roumet, C., Thomas, S. C., Tjoelker, M. G., Veneklaas, E., and Villar R.: The world-wide leaf economics spectrum, Nature, 428, 821-827, 2004.
Xiaoshan, Z., Yujing, M., Wenzhi, S., and Yahui, Z.: Seasonal variations of isoprene emissions from deciduous trees, Atmos. Environ., 34, 3027-3032, 2000.

Zemankova, K.: Measurements of emission factors from forest species common in the Czech Republic, in: VOCBAS report, Department of Meteorology and Environment Protection, Charles University, Prag, 7 pp., 2007.

Zimmer, W., Brüggemann, N., Emeis, S., Giersch, C., Lehning, A., Steinbrecher, R., and Schnitzler, J. P.: Process-based modeling of isoprene emission by oak leaves, Plant Cell Environ., 23, 585595, 2000.

Zimmerman, P. R.: Determination of emission rates of hydrocarbons from indigenous species of vegetation in the Tampa/St Petersburg, Florida Area, EPA Contract No. 904/9-77-028, prepared for Environmental Protection Agency, Environmental Protection Agency, Atlanta, Georgia, USA, 1979. 